TALENT MANAGEMENT MOTIVES AND PRACTICES IN AN EMERGING

MARKET: A COMPARISON BETWEEN MNES AND LOCAL FIRMS

by

Ekrem Tatoglu ${ }^{a}$, Alison J. Glaister ${ }^{\mathrm{b}}$, Mehmet Demirbag ${ }^{\mathrm{c}}$

${ }^{a}$ Professor of International Business, Chair in International Trade and Business, Bahcesehir University, Besiktas, Istanbul, 34349, Turkey. E-mail: ekrem.tatoglu@ bahcesehir.edu.tr

${ }^{\mathrm{b}}$ Lecturer in Strategic HRM, Aston Business School, Aston University, Birmingham, United Kingdom. E-mail: a.glaister@ aston.ac.uk

${ }^{c}$ Professor of International Business, Essex Business School. University of Essex, United Kingdom, E-mail: mdemirc@essex.ac.uk

${ }^{\#}$ Corresponding author:

Professor Mehmet Demirbag

Management Science and Entrepreneurship Group

Essex Business School

University of Essex

Elmer Approach

Southend-on-Sea SS1 1LW

United Kingdom

Phone: +44 (0) 1702328276

E-mail: mdemirc@essex.ac.uk 


\title{
Talent management motives and practices in an emerging market: A comparison between MNEs and local firms
}

\begin{abstract}
This paper compares the differences in talent management motivations and practices between MNEs and local firms in the emerging market of Turkey. It uses institutional theory and the resource based view of the firm to explain these differences. Examining data from 201 firms the findings show significant differences between the talent management motives of MNEs and local firms, with MNEs having more tactical motivations for their talent management systems. The study also shows significant differences in the talent management practices between MNEs and local firms, with MNEs implementing more robust systems of talent management overall. The findings indicate that the motives for TM and the practices that are pursued by organizations are society-bound. The study of TM motives and practices has to be framed within the context of the institution as this shapes the way in which actors perceive and respond to environmental and organizational stimuli and the extent to which they seek to protect the rules that shape and structure their environments.
\end{abstract}

Keywords: Talent management, Institutional theory, Resource based view, Emerging markets, Turkey. 


\section{Talent management motives and practices and practices in an emerging market: A comparison between MNEs and local firms}

\section{Introduction}

The employment context is changing as organizations face demographic and economic pressures including an increase in life expectancy, declining birth rates, the increasing mobility of human capital through globalization and a greater shift towards knowledge based economies (Beechler \& Woodward, 2009). As globalization intensifies the talent available to organisations is set to grow, however, Meyskens, Von Glinow, Werther, \& Clarke (2009: 1439) affirm that the ability to "attract, motivate and retain" this talent will become ever more difficult with increasing turnover costs including the loss of corporate memory, productivity and intellectual and social capital. Talent management (TM) issues - those relating to the 'future-proofing' of an organization's human capital pool - are caused by increasing difficulties in sourcing the right skills in the labour market at the right time, the difficulties in developing a workforce that is able to keep pace with technology changes, and the diverse expectations of the employment relationship amongst baby boomers and generations $\mathrm{X}$ and $\mathrm{Y}$ (Pelster et al., 2013). These talent shortages highlight the need for organizations to adopt strategic approaches to TM yet scholarly research suggests a disconnect between the two (Al Ariss et al., 2014, Chadee \& Raman, 2012, Mellahi \& Collings, 2010).

While scholarly interest in TM is increasing (see for example Meyers \& van Woerkom, 2014, Minbaeva \& Collings, 2013, Nijs et al., 2014, Schiemann, 2014, Sonnenberg et al., 2014, Tatli et al., 2013, Vaiman \& Collings, 2013, Skuza et al., 2013), only one third of scholarly output is empirical in nature (Thunnissen et al., 2013). Further, Dries (2013a:273) suggests that "scholarly peer-reviewed literature is still lagging behind". Context specific research has recently focused on India and China (Hartmann et al., 2010, Teagarden et al., 2008, Illes et al., 2010, Budhwar, 2012, Cooke et al., 2014, Chadee and Raman, 2012), Oman (Sidani \& Al Ariss, 2014), Vietnam (Kim et al., 2012), Spain (Valverde et al., 2013), Poland, (Skuza et al., 2013), France (Chabault et al., 2012) and Germany (Festing et al., 2013). However, despite these numerous studies, there remains a need to examine further the 
contextual nature of TM and the prevalence of diverse TM practices within organizations (Dries, 2013b, Dries, 2013a, Festing et al., 2013, Illes et al., 2010, Sidani \& Al Ariss, 2014), and TM practices in emerging market economies (Cooke et al., 2014, Farndale et al., 2010). Sparrow et al. (2014) stress the need to consider the global context in furthering our understanding of the conceptualisation and operationalization of TM and that recruiting and retaining talented labour is becoming increasingly difficult within emerging markets.

We respond to this need by examining TM motives and practices and how they differ between multinational enterprises (MNEs) and local firms in the emerging market context of Turkey. TM considerations are of prime importance in emerging market economies because of economic growth, demographic trends, the characteristics of employees and changing attitudes and beliefs to work and more specifically, Turkish firms have tended to rely on foreign partners for their new management practices (Wasti, 1998, Doh et al., 2014). While there has been much debate over the past two decades on the extent to which countries experience positive spillover effects from MNE investment, the same issues are critical in the discussion of TM strategy (Farndale et al., 2010, Sparrow et al., 2013).

The contribution of this paper is two-fold. First, it advances the theoretical understanding of TM. By considering the resource-based view of the firm (RBV) and the various perspectives of institutional theory, the paper shows the limited explanatory power of RBV in determining the motives for TM and the nature of practice. Instead, the paper explains how the different perspectives of institutional theory can be used to understand both the motives for TM and its subsequent practice and thus develop a more nuanced understanding of TM systems. Second, a lacuna exists in our understanding of TM in emerging market economies (Dries, 2013a, Festing et al., 2013, Sidani \& Al Ariss, 2014, Sparrow et al., 2014, Cooke et al., 2014, Farndale et al., 2010) where the retention of talented labour is becoming increasingly difficult (Sparrow et al., 2014). This paper makes a contribution in filling this gap. To the best of our knowledge, this is the first study to compare and examine TM in MNEs and local firms within the context of Turkey. Turkey provides an interesting site for this research because not only is it considered to be an emerging market economy, but TM is becoming of prime importance to the Turkish economy - driven by 
growing investments in infrastructure, rising MNE demands for skilled labour, and a shortage of leadership talent (Ali, 2011; Demirbag et al., 2014). Through a comparison of MNE and local firm practice, the paper compares the motives that guide TM implementation and examines the different TM practices between these two organizational types.

The paper is set out as follows: Firstly, the theoretical underpinnings of TM are discussed in light of the extant research in the area. The institutional context of the study is then examined with a particular focus on the extent to which Western human resource management (HRM) practices are being adopted by Turkish firms. The hypotheses are introduced through a discussion of diverse TM needs within MNEs and local firms. This is followed by the research methods adopted for the study. The findings are then discussed in light of the literature together with implications for practitioners and avenues for further research.

\section{Talent management, underpinning theory and hypothesis development}

TM is focused on the identification of key positions which add to the competitive advantage of the firm, the HRM architecture (processes, systems and practices) used to support this and the impact of these on firm performance and, given the competition for highvalue labour, the impact on the psychological contract of the employee (Mellahi \& Collings, 2010; Cappelli, 2008; Tarique \& Schuler, 2010; Huang \& Tansley, 2012). There are four philosophies that dominate TM discourse - people, pools, positions and practice (Collings \& Mellahi, 2009, Scullion \& Collings, 2010, Sparrow et al., 2014) and the key challenge for each is to establish a consensus of what TM actually means and how it can be differentiated from HRM/IHRM traditions (Scullion \& Collings, 2010, Lewis \& Heckmann, 2006).

There are a series of key tensions that are inherent within each of these philosophies. The people approach which focuses TM on a core set of individuals, suffers from managerial bias and bounded rationality, relying on the memory recall of key managers to identify who is to be considered talent (Sparrow \& Makram, 2015). The pools approach involves the identification of groups and clusters of individuals who have differential impact on an organizations performance and brings with it a consideration of organizational justice and 
stakeholder theory as it suggests an exclusive approach to TM (Gelens et al., 2014, GallardoGallardo et al., 2013, Thunnissen et al., 2013). While informing talented individuals of their special status as 'talent' has a motivational effect (Björkman et al., 2013), a pools approach to TM can create inequitable systems, widening pay differentials, overemphasizing individual performance while promoting the talent of a few key individuals within the business (Mellahi \& Collings, 2010, Guthridge et al., 2008, Ashton et al., 2010). Delong and Vijayaraghavan (2003) and Cooke et al. (2014) warn of the negative impacts exclusive TM systems can cause and the danger inherent in ignoring their emotional effects. The positions approach advocated by Becker and Huselid (2006) suggests that organizations make disproportional investments in those positions that add to the competitive advantage of the firm - ensuring the role of a differentiated HRM architecture (Lepak \& Snell, 1999), but the challenge for all organizations, especially those that are distributed globally, is the issue of internal equity and consistent performance management (Minbaeva \& Collings, 2013). The final approach - and the focus of this paper is the practice approach. The practice approach suggests a need for a sophisticated suite of HRM policies and practices that are also capable of developing the skills and competencies of global talent, yet as with the perennial issues connecting HRM and performance, there are issues in defining the bundles of HRM that constitute effective TM (Ortlieb \& Sieben, 2011, Meyers \& van Woerkom, 2014) and establishing a link between these, broader organizational strategies and institutional and worker contexts (Mellahi \& Collings, 2010, Cappelli, 2008, Tarique \& Schuler, 2010, Huang \& Tansley, 2012)

The field of TM and its focus on a differentiated architecture strongly connect TM to the achievement of sustainable competitive advantage (Collings \& Mellahi, 2013). Sparrow et al. (2014) consider the subject of TM to be a bridge field -drawing upon ideas from marketing, operations and HRM - each emphasising human capital thinking, where it is assumed that those talented employees will add value to their organization and will generate superior results (Sparrow \& Makram, 2015, Collings \& Mellahi, 2009) and organizations will seek to develop key people that fit their context and will create a nurturing environment commensurate with their talent objectives (Chabault et al., 2012) 
TM systems can therefore be underpinned by the resource-based view of the firm in that they are instrumental in identifying and developing resources that are valuable (the resource enables the organization to respond to threats and opportunities), rare (the resource is controlled by a small number of competing firms), inimitable (other firms will face a cost disadvantage in obtaining/developing the resource) and non-substitutable (the advantage cannot be achieved through other means) (Barney, 1991, Barney, 2002). It is important to note that in order to conduct a resource based analysis, Barney (2002) also considers the 'question' of organization i.e. the systems, procedures and policies that support the exploitation of these resources. From a TM perspective, these systems should be designed to create, capture, leverage and protect value that is derived from an organization's talent assets (Sparrow \& Makram, 2015).

According to Oliver (1997), RBV is underpinned by a core set of assumptions: It assumes an economic motivation, based on managerial choice motivated by efficiency; that the choices made are value-maximising, that managers will seek to optimise these choices; and that through a systematic assessment, optimal decisions will be reached. Whilst RBV is governed by an economic rationale, the isolating mechanisms that prevent the replication of these resources are a function of causal ambiguity and social complexity. According to Peteraf (1993:187) “...the firm owning the assets is likely to have a strong advantage in extending them over other firms. In part, this advantage is informational, based on complex and tacit understandings, not easily accessible to outsiders". It is not only the identification of resources that is important, but how they are mobilised within the systems in which they reside. This assumes an understanding of an organization's strategy, values, mission, culture and history.

Bowman and Hird (2014) suggest that the application of RBV to TM is premised on collective interactions and path dependence rather than the actions of key individuals. TM is filtered through an historical lens that subsequently guides action. Therefore, for TM to be effective across different cultures, TM strategies need to attend to broader motives other than economic. They need to consider the institutional context in which decisions are made as well 
as the nature of occupations, the role of social status and nature of wealth distribution (Vaiman \& Brewster, 2015).

Institutional theory itself is subject to diverse perspectives. Rational choice institutionalism considers institutions to be "shared patterns of action that economic agents devise in order to overcome uncertainty" (Morgan \& Hauptmeier, 2014:191). These shared patterns assume that organizations perceive similar threats within the external environment and that new structures are created that will use features of the old regime in new ways. Historical institutionalism (Steinmo et al., 1992) suggests that rather than being products of rational choices, institutions are path dependent and rooted in the historical preferences of stakeholders. This approach views institutions as static and radical institutional change as impossible. Sociological institutionalism on the other hand, views organizations as social entities that seek approval within environments that are socially constructed (Scott, 1987). Sociological institutionalism predicts that the normative expectations of society shape organizational behaviour and that these become embedded and assume "rule-like status" (Martinez \& Dacin, 1999:78). According to DiMaggio and Powell (1983), these "rules" are created through three key isomorphic pressures: coercive where behavioural patterns are imposed; mimetic where attempts are made to copy practices that are perceived to be superior, and finally normative through the dissemination of practices by professional organizations including professional bodies, universities and consultancies. Organizations will conform, knowingly or otherwise, to their corresponding institutional settings in order to achieve a sense of legitimacy (Collings et al., 2010b).

Despite the nuances in each of the institutional theory perspectives, embeddedness is a fundamental consideration when examining the differences between MNEs and local firms as it highlights the importance of high density and enduring social, economic and professional networks that shape both expectation and opportunity (Granovetter, 1985, Uzzi, 1996). McEvily and Zaheer (1999:1134) argue that local businesses work with regional institutions who act as network intermediaries - in this way local firms are able to develop competitive capabilities. Indigenous firms are guided by a normative rationality consistent with the values and the traditions of the given society, regardless of whether these are historical, rational or 
sociological. Oliver (1997: 702) suggests that within an institutional framework, decisions are value-laden and based on social context, which in turn can limit the take-up of new ways ideas and ways of operating. Employees may be afraid to learn new skills or digress from the more traditional ways of doing things. While RBV suggests that inimitability is a mobility barrier, institutional barriers focus on the extent to which resources are politically/culturally acceptable. Therefore, institutional differences between countries impact all aspects of an organization's practice (Paauwe \& Boselie, 2003).

RBV focuses on the development of human capital through the lens of economics, but human capital cannot be considered in isolation, it needs to be combined with social capital (Collings, 2014). Social capital is focused on those features in organizations that "facilitate collective action in pursuit of shared goals such as trust, culture, social support, social exchange, psychological contract, informal organization social and interfirm networks" (Tempest et al., 2004: 1525). MNEs are subject to structural, geographical and social distance (Minbaeva \& Collings, 2013) and the facilitation of social capital is necessarily an HRM activity that is concentrated on "diagnosing and changing mind sets and mental models" (Losey et al., 2005:170). A complex array of TM practices and systems supports RBV theory in that they help to produce and sustain specific resource characteristics, yet from an institutional perspective, local firms have a specific advantage in that social capital is an inherent feature of the system itself - individuals are pre-socialised and employees work within an organization that is embedded within the social system. Local firms will therefore have indigenous systems that reflect employee expectations (Saini \& Budhwar, 2004, Doh et al., 2014) and these enduring social systems will make it hard for MNEs to transfer their TM practices (Cooke et al., 2014). As TM is contingent upon corporate strategy, labour market supply, governmental initiatives and institutional drivers (Chabault et al., 2012, Iles, 2013, Al Ariss et al., 2014, Joyce \& Slocum, 2012), it is important to consider the idiosyncrasies of Turkey's operating environment.

Turkey is classified as an emerging market economy that has experienced a series of economic reforms since 1983. These reforms have been responsible for transforming the economy through privatization, foreign trade and foreign direct investment (FDI) (Gurbuz \& 
Mert, 2011) and the country is more likely to attract more FDI than established market economies (Horwitz, 2012). OECD (2012) figures illustrate that Turkey has experienced strong economic growth rising from - 4.8 per cent in 2009 to 8.9 per cent in 2010 and in 2014 it was ranked $44^{\text {th }}$ out of 148 countries on the Global Competitiveness Index, due in part, to its infrastructure and business environment improvements (Euromonitor, 2014). Turkey's total volume of foreign trade has reached a record high level of $\$ 403$ billion as of 2013 and cumulative inward FDI inflows have amounted to $\$ 135$ billion over the past decade (Republic of Turkey - Ministry of Economy, 2014). Between 2014 and 2015, GDP growth is expected to rise from 4 per cent to 5.1 per cent, explained in part by a variety of construction projects and investments in ports and airports (Euromonitor, 2014).

$\mathrm{TM}$ is becoming of prime importance to the Turkish economy - driven by growing investments in infrastructure, rising MNE demands for skilled labour, and a shortage of leadership talent (Ali, 2011) and complemented by a large and young population accounting for 41.5 per cent of the total population (Euromonitor, 2014). There are some sectors within the Turkish economy that are considered to be financially and organizationally strong enough to lobby the state in favour of their business interests (Ali, 2011), however, the majority of businesses are classified as small and medium sized enterprises (SMEs) and account for $81.3 \%$ of total employment (Glaister et al., 2008; Elci, 2011). These SMEs tend to be family owned and dependent upon a range of government incentives to offset labour market rigidities poor labour relations including a high minimum wage and legislation restricting the use and cost of redundancy. (Elci, 2011, Gurbuz \& Mert, 2011, Lennard, 2014, Çamlica \& Nibbe, 2014).

HRM practice within these organizations has tended to reflect Turkish culture (Tüzüner, 2014), one that is characterised by unequal power distribution and uncertainty avoidance, with Turkish managers favouring top-down communication in a parent-child relationship, and the concept of 'family' within the organization continues to shape behaviour (Wasti, 1998, Tüzüner, 2014, Kabasakal \& Dastmalchian, 2001). Turkey is considered to be one of the most collectivist societies in the world (Kabasakal \& Dastmalchian, 2001). Senior positions are held by family members who are expected to solve 
personal problems and provide pastoral support and this is supported by hierarchical and highly centralised organization structures (Tüzüner, 2014, Kaya, 2006). Organizations, especially those in the public sector, rely heavily on favouritism and the most common disputes amongst Turkish businesses involve late payment to employees, job discrimination, promotion and rewards, and unregistered employment. Career management and promotion is dependent upon seniority. This suggests a more limited role for the western concept and TM practices.

However, local companies do form international partnerships in order to learn new managerial tools and techniques and Wasti (1998:625) argues that MNEs will have more "latitude" in transferring their home-country practice. Tüzüner (2014), Sayım (2010), and Ercek (2006) suggest that among larger private sector organizations and those that are active in international markets, Western style HRM practices are being adopted to modernise Turkish businesses. These practices are structured and focused on business strategy and include reward management and high-road HRM strategies, each complemented by a degree of practice localisation (Glaister et al., 2008). Gurbuz and Mert's (2011) study finds strong positive correlations between Turkish employee job satisfaction and participation, teamwork, appraisal, training and pay. This is echoed by Collings et al. (2010b) confirming the link between employee satisfaction and merit-based promotion opportunities, communication and empowerment.

Despite some evidence of a positive embrace of Western high-road HRM practices, Collings et al. (2010b) suggest that the cultural characteristic of group orientation negates the positive outcomes of a performance management process and instead these become more politically motivated in order to avoid confrontation. Indeed, local firms tend to alter these performance management systems to suit their own values and culture (Keleş \& Aycan, 2011) and when combined with a lack of HRM board level representation, the suggestion of a ten year lag between Turkish HRM practice and that of the US (Tüzüner et al., 2014, Cranfield University, 2006), poor education standards and inadequate vocational education (Çamlıca \& Nibbe, 2014), the idiosyncrasies of the Turkish environment may prevent the successful transfer or Western TM practices unless highly localized. 
MNEs play an important role in the evolution of people practices in Turkey and spillover effects are evident as both local firms and MNEs compete for the same talent (Demirbag et al., 2015). MNEs require more sophisticated approaches to fill specific competency shortfalls, they provide incentives in order to retain key individuals and devise leadership rotation programs to maintain and develop technical talent (Garavan, 2012:2439). They may experience more pressure to adopt TM processes as they seek to achieve global integration through best practice adoption, while differentiating their employment offerings from local firms and creating a 'moveable' workforce, leveraging the diversity of their employment base (Beechler \& Woodward, 2009, McDonnell et al., 2010, Ashton et al., 2010). TM strategies create scale economies, improve access to local resources, assist the development of transnational capabilities, and facilitate access to different talent pools and capitalize on diverse worker perspectives (McWilliams et al., 2001, Tan \& Mahoney, 2003). MNEs are more likely to adopt innovative TM practices during a recession in order to retain and develop talent rather than acquire it (McCartney, 2010, Garavan, 2012, Mohamed et al., 2012). MNEs frequently engage in cross-subsidiary transfer of employees and the deployment of universal HRM systems help to allocate resources, identify and measure high performers and build organizational culture (Collings et al., 2010b, Collings et al., 2007, Wöcke et al., 2007).

According to Stahl et al. (2012), MNEs who have successful TM systems integrate business planning and TM processes, they combine practices to complement other parts of the HRM system, they foster ownership for TM across the organization and they maintain consistent brand identity. Of particular note is their mention of the need to balance the local with the global but at the same time, ensure corporate cultural embeddedness. Stahl et al. (2012:31) note that benefits from TM do not surface from best practice implementation; however they argue that MNEs are becoming similar but also increasingly sophisticated in their TM endeavours. Doh et al. (2010) also provide evidence to support the increasing sophistication of TM practices amongst MNEs. Focusing on India they describe MNEs engagement with CSR initiatives and 'soft' HRM people management practices, highlighting a degree of localisation. Cooke (2010) stresses the need to consider sectoral approaches, and 
in China MNEs in the high technology sector have more developed and responsive TM systems that focus on performance and reward.

A strategic approach to TM is centred on the need to support business and structure change, the planning of the workforce to cope with these changes and the achievement of strategic goals. A strategic approach is consistent with the assumptions of the RBV in that competitive resources are developed and supported by strategic systems that should equate to organizational process advantage and are embedded within the corporate culture (Boxall \& Purcell, 2011). Equally, strong corporate cultures within the MNE have the power to "transcend national institutions" (Rubery \& Grimshaw, 2003:199), change values (Bartlett et al., 2003) and shape conditions to suit their needs. Vaiman and Brewster (2015) suggest that institutional limits, in terms of cultural identity, can be overcome simply by selecting and training individuals who share a cultural fit with the recruiting organization.

The institutional setting impacts the MNE more than it does local firms, because MNEs are generally more susceptible to high levels of scrutiny and seek legitimacy in their new environment (Vaiman \& Brewster, 2015). Yet local firms are more entrenched in their ways and are products of their history and the culture in which they reside. That Turkish firms actively seek partnerships with foreign investors suggests a need to import new management expertise, but at the same time, the take-up of these new ideas is filtered through a valueladen lens where managers and employees may be motivated to resort to traditional ways of doing things (Oliver, 1997). These traditional, institutionally embedded ways of doing things equate to a more short-term, less systematised, tactical approach to TM which will respond to current needs and make the most efficient use of resources to develop leaders, to retain staff, to address skill shortages, to attract new recruits, and to redeploy staff to new roles. This discussion leads to the following hypotheses:

H1. As compared to local Turkish firms, MNE subsidiaries in Turkey will adopt a more strategic approach to their TM practices. 
H2. As compared to MNE subsidiaries in Turkey, local Turkish firms will adopt a more tactical approach to their TM practices.

The strategic and tactical motives for TM will shape the nature of practice. TM practices vary and it is impossible to define a clear bundle that will work in every context (Stahl et al., 2012, Tarique \& Schuler, 2010, Fernandez-Araoz et al., 2011). Instead, TM should create a clear employee value proposition that is consistent with an explicit brand identity and focused on the long-term career development opportunities of their talent (Stahl et al., 2012). Diverse bundles of TM practices within an MNE context serve as 'acclimatization tools' and include career portfolio building, mechanisms that facilitate job rotation, as well as internal and external secondments, coaching, mentoring and leadership development programs (Meyers et al., 2013). In China, TM tends to be HRM-led, and MNEs utilise standardized templates for performance appraisal alongside training and international job rotation and localized inducements including the provision of housing, career development, educational benefits and greater work autonomy (Guthridge et al., 2008, Hartmann et al., 2010). Budhwar (2012) suggests that the tight labour market in India provides stimulus for TM activities and MNEs adopt HRM-led standardised systems of career development and fast track schemes while embracing local expectations through the provision of loan schemes, participation schemes and free transportation.

Thus institutional duality (Kostova \& Roth, 2002) suggests that MNEs will seek to balance global standardisation with the needs of the local environment and local firms will be restricted by the nature of their institutional norms. As such it is expected that MNE practice will differ from that of local firms despite spillover effects. These differences are due to the ways in which local Turkish firms are managed, the role that is played by the HR function, the extent to which organizations seek a clear value proposition and the way in which they perceive their external environment.

There is evidence of an embrace of Western HRM practices amongst local firms in Turkey (Collings et al., 2010a, Gurbuz \& Mert, 2011, Sayım, 2010) but this development remains in a nascent state (Mohamed et al., 2012, Huang, 2000, Myloni et al., 2004, 
Budhwar, 2012). According to Tüzüner, (2014:448) "Some Turkish organizations try to adopt Western applications without giving importance to the basic factors of culture, phase of the organization's lifecycle and employee harmony". Local firms tend not to possess the organizational flexibility to cater for more comprehensive TM systems (Hiltrop, 1999, Mohamed et al., 2012, Skuza et al., 2013). Family firms will have fewer promotion opportunities and smaller organizations will engage much less in TM overall (Festing et al., 2013, Valverde et al., 2013). Valverde et al. (2013) suggest that collectivist cultures struggle with the individualistic and exclusive focus of TM programs. This, combined with the confined geographic scope of local firms and the fact that Turkey is reported to have the lowest higher education attainment levels of all the OECD members (Lennard, 2014) suggests a greater focus on the use of cheaper, internally focused, TM practices, including networking, internal teams, formal career plans, project working and the use of crossdisciplinary teams. These can be classified as work-based systems because of the distinct lack of HR intervention. These systems can be designed, managed and implemented by managers within the organization and will be perceived as requiring fewer resources (Valverde et al., 2013).

In contrast, MNEs are subject to structural, geographical and social distance (Minbaeva \& Collings, 2013). As such their focus is not only to develop human capital but social, political and cognitive capital (Farndale et al., 2010). Losey et al. (2005) consider the facilitation of social capital as an HRM activity and the TM systems in MNEs have to meet the motivations and expectations of global 'careerists' across different nationalities while at the same time achieving cultural consistency and strong norms and values that support their corporate strategies within diverse markets (Stahl et al., 2012). This suggests that TM in MNEs is becoming increasingly sophisticated with the need for new tools and metrics enabled through a developed HR function. Thus HRM-led systems will include more processoriented, focused TM interventions with which to develop a cadre of geocentric managers (cf. Perlmutter, 1969). These practices will include coaching, mentoring, a focus on recruitment and selection through assessment centres, graduate development programmes, succession plans, high flier schemes and formal off-the job training including university courses. 
However, HRM-led systems will be less apparent within local Turkish firms as they alter their HRM systems to suit their own values and rely more on family values and local connections (Keleş \& Aycan, 2011). HRM practice implementation lags behind the West by ten years (Tüzüner, 2014) and HR suffers from poor levels of board representation (Cranfield University, 2006). In Turkey, MNE subsidiaries have more developed and strategic HRM departments than their local counterparts who view HRM as a secondary consideration. (Mellahi et al., 2013). Kaya (2006) suggests that HRM is a developing concept in Turkey, with many firms still implementing a personnel management type role, explained in part by a cost reduction focus and a failure of Turkish managers to consider their employees as central to growth and success. This discussion leads to the following hypotheses:

H3. TM systems within local Turkish firms will be more work-based than TM systems of MNE subsidiaries in Turkey.

H4. MNE subsidiaries in Turkey will make more use of HRM-led systems than local Turkish firms.

MNEs depend on the development of global workers and international assignments accelerate the development of 'global careerists' and play a fundamental role in building social capital, exposing employees to corporate culture and aligning them to the goals of the organization (Bozkurt \& Mohr, 2011a, Stahl et al., 2012). International assignments extend personal networks, enable the sharing of tacit knowledge and the development of an individual's cultural intelligence (Collings, 2014, Bücker, 2014). Such practices can include training in international operations, international assignments and international project teams. Longer assignments enable a greater depth of awareness and social ties that endure beyond the assignment, whereas project teams and shorter assignments facilitate contact with a wider number of colleagues within the organization (Bozkurt \& Mohr, 2011a). Through these types of practices MNE subsidiaries are able to develop international careers that create a valuable and hard-to-imitate experience (Stahl et al., 2007, Björkman et al., 2013). Typically, such 
international systems are implemented using either a control or a coordination rationale. According to Cerdin and Brewster (2014), an agenda of control is not likely to be connected to TM whereas MNEs pursuing a coordination rationale are more likely to focus on employee development and incorporate these international systems into their TM practices. Indeed, if TM is governed by the 'positions' philosophy then international assignments are central to global mobility (Collings, 2014). Such assignments not only develop leadership ability but also address the issues of coordination, cost control and flexibility (Collings \& Scullion, 2012, Farndale et al., 2014). According to Beulen (2009) employees working in developing economies view the opportunity to work away from home in different ways. For example, within the Indian IT sector, the opportunity to work in diverse locations offers status, but in other emerging economies workers tend to prefer locations that are close to home. This, combined with a reduced focus on HRM-led practices amongst local Turkish firms and less international activity vis-a-vis their MNE counterparts, leads to the following hypothesis:

H5. MNE subsidiaries in Turkey will make more use of international systems than local Turkish firms.

Career portfolio building includes TM practices such as internal secondments, job rotation and external secondments, ensuring that employees work in different roles and in different environments. Evidence suggests that MNEs are starting to use more flexible forms of global staffing instead of more costly traditional expatriate assignments and are engaging in job rotation and secondment activities (Farndale et al., 2014, Farndale et al., 2010). According to Fernandez-Araoz et al. (2011) job rotations are the most powerful tool in developing managerial talent, placing them in challenging roles. They also assist the development of social ties between business units and assist knowledge sharing and trust relationships (Bozkurt \& Mohr, 2011b, Farndale et al., 2014, Farndale et al., 2010, Wickramasinghe \& Weliwitigoda, 2011).

Yet these systems also present challenges for MNEs. Groysberg (2012) suggests that when transferred to a different organization, talented employees experience reductions in 
performance for around five years, thus emphasising the need for more contextual understanding of the factors that enable superior performance. In addition, external secondments and transfers can lead to a shift in commitment towards the new firm or subsidiary at the expense of the old and can restrict the development of deeper levels of expertise undermining quality output (Bozkurt \& Mohr, 2011a, Nalbantian \& Guzzo, 2009). This suggests that MNEs will be able to absorb such costs and have experimented sufficiently to understand the extent to which career portfolio systems can assist their global operations. Career portfolio building through job rotation and secondments is considered to be high risk and costly with the potential to compromise accountability, demoralize managers and disrupt operations (Fernandez-Araoz et al., 2011, Nalbantian \& Guzzo, 2009), as such they may not be suited to risk averse (Kabasakal \& Dastmalchian, 2001), local Turkish firms with smaller budgets and a reduced focus on HRM-led systems. This discussion leads to the following hypothesis:

H6. MNEs in Turkey will make more use of career portfolio building than local Turkish firms.

The research framework is shown in Figure 1.

\section{[Insert Figure 1 over here]}

\section{Research methods}

\subsection{Sample and data collection}

The sampling frame for MNE subsidiaries in Turkey was drawn from the database of YASED (Association for Foreign Capital Coordination) member's list. YASED is a nonprofit, private sector organization founded in 1980 to encourage and monitor FDI in Turkey. Its members are composed of both foreign and local senior managers of MNE subsidiaries operating in Turkey. As of 2013, the database of YASED consists of 221 member companies. 
The sampling frame for indigenous firms in Turkey were drawn from the website of TOBB (The Union of Chambers of Commerce, Industry, Maritime Trade and Commodity Exchanges of Turkey, available at http://www.tobb.org.tr), which provides an industrial database that contains over 40,000 firms that are registered to any of 10 Chambers of Industry, 19 Chambers of Trade and 64 Chambers of Industry and Trade in Turkey. Within this sample frame, small companies of fewer than 50 employees were excluded. This was not viewed as a serious threat to the study as many such companies are likely to be managed entrepreneurially and so have no recognizable HRM system. Through a random sampling selection procedure, a total of 500 firms was generated and constituted the sampling frame for the study.

A carefully constructed questionnaire which was originally developed in English was translated from English to Turkish and then re-translated into English by a second party to ensure accuracy in translation. This process of 'back translation' is useful in identifying misinterpretations and misunderstandings before the questionnaire is administered. To further ensure the veracity of the translation, two bilingual translators were used in tandem to compare the back translated English and Turkish versions of the questionnaire and make any necessary changes. A Turkish version of the questionnaire and a covering letter were posted to the general manager of subsidiary and indigenous firm along with a cover letter requesting that the general manager, or his/her senior executive in charge of HRM within the organization, should complete it. In case of MNE subsidiaries, however, an original English version was at times used when the respondent was a non-Turkish national.

For MNE subsidiaries, after one reminder, a total of 84 questionnaires were returned, of which 75 were usable (an effective response rate of 33.9\%). For local firms, a total of 141 questionnaires were returned following one reminder, of which 126 were usable (an effective response rate of $25.2 \%$ ). Both response rates were satisfactory, given the nature of the questionnaire and the type of potential respondent.

A test for non-response bias for the mail survey for each group of sample firms was conducted by comparing the first wave of survey responses to the last wave of survey responses (Armstrong \& Overton, 1977). Almost 50\% of the surveys were randomly selected 
for each of the first and last waves of questionnaires received, and t-tests were performed on the scores across groups. The test results indicated no significant difference in the responses between early and late respondents $(p>0.1)$ for any of the variables used in this study. For each sample, ANOVA tests were also used to compare the respondent firms with nonrespondent firms across the main characteristics of the sample such as industry type, firm size and geographical location, and again showed no systematic differences $(p>0.1)$. Hence, no response bias was evident.

The characteristics of the questionnaire respondent firms for each group of sample firms are summarized in Table 1.

\section{[Insert Table 1 over here]}

\subsection{Measurement of variables}

The measures used to capture data for the empirical analyses were drawn from previously administered questionnaires used earlier by Lewis (2009), the Chartered Institute of Personnel and Development (CIPD) $(2011,2012)$ and the CRANET survey (Cranfield University, 2003).

The dependent variable was categorical and measured by a dummy variable. A value of one was assigned for MNE subsidiaries operating in Turkey, while a zero value was assigned for domestic firms in Turkey. The independent variables were measured as follows:

TM motives were measured by a total of 10 motives used earlier by the CIPD and the CRANET survey (CIPD, 2011, Cranfield University, 2003). Relying on a five-point Likert scale $($ ranging from $1=$ strongly disagree to $5=$ strongly agree), the respondents were asked to indicate the objectives of the TM practices in their firms.

The relative use of TM practices was measured through a total of $20 \mathrm{TM}$ practices developed by the CIPD. Again, using five-point scale items $(1=$ never used to $5=$ used very extensively) respondents were asked to identify the extent of use of each TM practice for career development of managers in their firms. 
Subsidiary-level effects were captured by the following three control variables which included subsidiary size, age and industry sector.

Subsidiary size was measured by five size categories determined by the number of employees, as shown in Table 1. An ordinal variable was created that takes the value from 1 to 5 to represent each category.

Subsidiary age was measured using the logarithm of the total number of years elapsed since the establishment of subsidiary.

To control for industry variations, a dummy variable was created for industry categories where the overall sample of subsidiaries was broadly split into two categories including manufacturing vs. services.

\subsection{Common method bias}

As the independent and dependent constructs are measured from the same source, it might be possible that there will be common method variance (CMV) bias, which may contaminate all measures in the same direction (Podsakoff, MacKenzie, Lee, \& Podsakoff, 2003). Hence, it is critical to assess whether CMV bias is likely to influence the results. In line with the statistical procedures proposed by Widaman (1985) and Carlson and Kacmar (2000), CMV was checked in the following manner. All the observed variables in the measurement model are loaded to their assigned latent factors as well as to a single unmeasured latent method factor. The fit indices resulting from this model is then compared to the fit indices for the actual measurement model. The latent method factor model was found to be far too poor $\left(\chi 2 / \mathrm{df}=7.1, \mathrm{RMR}=0.1 ; \chi^{2} / \mathrm{df}=3.1, \mathrm{RMR}=0.17\right)$ compared to the actual measurement model $(\chi 2 / \mathrm{df}=3.9, \mathrm{RMR}=0.04 ; \chi 2 / \mathrm{df}=2.4, \mathrm{RMR}=0.08)$ for both $\mathrm{TM}$ motives and TM practices, respectively thereby establishes lack of a serious CMV bias.

\section{Results}

The data analysis testing the hypothesized relationships in our research framework was conducted at three stages. In the first stage, exploratory factor analyses (EFA) with varimax rotation were performed to determine the underlying dimensions of TM motives and TM 
practices in order to test for discriminant validity between studied variables (Mentzer \& Flint, 1997). The next stage involved testing of the measurement models for each construct using confirmatory factor analysis (CFA) in order to determine if the extracted dimensions in earlier stage are in fact unidimensional (testing for convergent validity) (Garver \& Mentzer, 1999) and offered a good fit to the data. Finally, due to the nature of the dependent variable, a binary logistic regression procedure was used in testing the study's hypotheses. The binomial logistic model explains to what extent the relative importance of TM motives as well as the emphasis on the implementation of TM practices varies between Turkish firms and MNE subsidiaries. A positive sign on the independent variable coefficients indicates the likelihood of the higher level of importance of TM motives and emphasis placed on the use of TM practices by MNE subsidiaries in Turkey, while negative sign indicates that of the higher level of importance and/or emphasis by domestic firms. These stages are discussed in more detail in the following subsections.

\subsection{Exploratory factor analysis (EFA)}

Due to potential conceptual and statistical overlap (Spearman correlation coefficients between the constituent items of TM motives and TM practices constructs revealed a number of low to moderate inter-correlations), an attempt was made to produce parsimonious set of distinct non-overlapping variables from the full set of items underlying each construct. EFA with varimax rotation was performed separately on the TM motives and TM practices in order to extract the dimensions of each construct for the full sample of firms. Tables 2 and 3 show the results of EFA for TM motives and TM practices, respectively.

Table 2 indicates that the EFA on the full set of 10 TM motives yielded two factors with eigenvalues greater than 1, as shown in Table 2. Based on the item loadings, these two factors were respectively labelled as strategically orientated (TMM1) and tactically orientated (TMM2), which explained 63.79 per cent of the observed variance. The Cronbach alpha values of reliability for the underlying factors are 0.85 and 0.83 , respectively, suggesting satisfactory level of construct reliability (Nunnally, 1978). 


\section{[Insert Table 2 over here]}

Similarly, EFA was undertaken to produce a set of parsimonious distinct nonoverlapping dimensions of TM practices from the full set of 20 items. The factor analysis produced four factors which accounted for 72.71 per cent of the observed variance, as shown in Table 3. These factors were labelled as work-based systems (TMP1), HRM-led systems (TMP2), international systems (TMP3) and career portfolio building (TMP4). Cronbach alphas for the underlying factors range between 0.94 and 0.77 , exhibiting a satisfactory level of construct reliability.

\section{[Insert Table 3 over here]}

\subsection{Confirmatory factor analysis (CFA)}

This stage is also known as testing the measurement model, where the constructs of TM motives and TM practices were tested using the first order confirmatory factor model to assess construct validity using the method of maximum likelihood. The results consistently supported the factor structure for both constructs as discussed earlier in the EFA stage. The CFA technique is based on the comparison of variance-covariance matrix obtained from the sample to the one obtained from the model. The measurement model results at the aggregate level for TM motives and TM practices are presented in Tables 4 and 5, respectively.

\section{[Insert Tables 4 and 5 over here]}

The figures in Tables 4 to 5 exhibit the standardized regression weight between each manifest variable and its corresponding latent variable. All the observed variables have a standardized loading of more than 0.5 attesting the convergent validity of the measures. The goodness of fit statistics for TM motives and TM practices are shown in Table 6. The resulting measurement models and their respective observed variables for both constructs indicate an acceptable fit. The values of $\chi 2 / \mathrm{df}$ ratio vary between 2.42 and 3.87 . This ratio should be within the range of $0-5$ where lower values indicating a better fit. In addition, the 
GFI, AGFI and CFI for TM motives and TM practices are highly satisfactory, as they are very close to a value of 1.0 , which denotes a perfect fit. The results attest the construct validity for the measurement models of both constructs.

\section{[Insert Table 6 over here]}

\subsection{Hypothesis testing}

Due to the nature of the dependent variable, the hypothesized relationships were tested through a binary logistic regression procedure, which estimates the probability of an event occurring. The binary logistic model can be denoted as:

$$
P(Y \mathrm{i}=1)=1 /[1+\exp (-a-X \mathrm{i} B)]
$$

where $Y \mathrm{i}$ is the dependent variable, defined by a dummy variable either 1 or 0 . The value of 1 denotes the probability of an event occurring rather than another as shown by the value of 0 . $X \mathrm{i}$ is the vector of independent variables for $i$ th observation, $a$ is the intercept parameter, $B$ is the vector of the regression parameters (Amemiya, 1981). The regression coefficients estimate the impact of the independent variables on the probability of an event that occurs. A positive sign for the coefficient means that the variable increases the probability of the event occurring, a negative sign signifies the opposite. The maximum likelihood estimates of the parameters were obtained employing logistic regression. The explanatory power of the model is assessed using the model chi-square statistics, which test the null hypotheses that all parameter coefficients are zero, except the intercept term. The predictive ability of the model can be determined by the correct ratio, which shows the percentage reduction in classification errors with respect to random selection. However, to identify an acceptable level of predictive accuracy, the obtained correct ratio has to be compared to the rate that would have been obtained by chance. In the case of unequal group sizes the standard to calculate this rate should be proportional chance criterion. The formula for this criterion is: $\alpha^{2}+(1-\alpha)^{2}$ where $\alpha$ is the proportion of cases in group 1 and $1-\alpha$ is the proportion of cases 
in group 2. For a rough estimate of the acceptable level of predictive accuracy, Hair, Black, Babin, Anderson and Tatham (2006) suggest that the correct ratio should be at least onefourth greater than the proportional chance criterion.

Prior to running the binomial logistic regression, a correlation matrix of the variables was prepared. The pairwise correlations were not large enough to warrant concern about possible multicollinearity problems. Table 7 presents correlation coefficients of independent variables in the study.

\section{[Insert Table 7 over here]}

Table 8 shows the results of the logistic regression where the Turkish firms were taken as the base and given a zero value. The binomial logistic model explains to what extent the relative importance of TM motives as well as the relative use of TM practices varies between Turkish firms and MNE subsidiaries. A positive sign on the independent variable coefficients indicates the likelihood of the higher level of importance attached to TM motives and also that of the higher level of use of TM practices by MNE subsidiaries in Turkey, while negative sign indicates that of the higher level importance of TM motives and use of TM practices by domestic firms.

A total of eight logistic regression models were estimated, as shown in Table 8. In the first step, the control variables were entered (Model 1). Of these variables, only the subsidiary size (SIZE) had positive and significant coefficients. Neither the subsidiary age (AGE) nor industry sector (INDUSTRY) had significant coefficients in all eight models in Table 8. The individual effects of the hypothesized variables were then tested in Models 2 to 7, and the full model including all independent variables along with the control variables was tested in Model 8. All eight models have high overall explanatory power with significant chisquare values $(p<0.01)$. All the models have a good fit with correct ratios ranging from $79 \%$ to $71 \%$ of the observations, rates that are higher than would be expected by chance. The specificity (i.e. capacity to correctly predict Turkish firms) of the eight models ranges from $90 \%$ to $83 \%$, while their sensitivity (i.e. capacity to correctly predict MNE subsidiaries) 
ranges from $64 \%$ to $47 \%$. Pseudo R-square measures confirm that the models have adequate explanatory power.

\section{[Insert Table 8 over here]}

H1 is not supported, as the coefficient of strategically orientated (TMM1) TM motives is not significant in Models 2 and 8 suggesting that MNE subsidiaries do not differ from domestic Turkish firms with respect to the relative importance of strategic motives for TM.

No support is found for H2. The coefficient of tactically orientated (TMM2) TM motives is positive and significant $(p<0.01)$ in Models 3 and 8 , which is at odds with our expectation in $\mathrm{H} 2$. This finding suggests that there exists significant difference between MNE subsidiaries and Turkish firms regarding the level of importance placed on tactical motives for TM. As compared to domestic Turkish firms, MNE subsidiaries in Turkey are found to have more tactical approach towards TM motives.

Contrary to our expectation in $\mathrm{H} 3$, the coefficient of work-based systems is positive and significant in Models $4(p<0.05)$ and $8(p<0.1)$ contradicting the view that TM systems within local Turkish firms will be more work-based than TM systems of MNE subsidiaries in Turkey.

There is some support for $\mathrm{H} 4$, as the coefficient of HRM-led systems is positive and significant in Models 5 and $8(p<0.05)$. This finding confirms the argument that MNE subsidiaries in Turkey will make more use of HRM-led systems than local Turkish firms.

In a similar vein, there is a strong support for H5. The positive and significant coefficients for international systems in Models 6 and $8(p<0.01)$ corroborate the view that MNE subsidiaries in Turkey will make more use of international systems than local Turkish firms.

Finally, Table 8 shows that there is no support for H6. The coefficient of career portfolio building is not significant in Models 7 and 8, suggesting that MNE subsidiaries do not differ from local Turkish firms with respect to the use of career portfolio planning initiatives. 


\section{Discussion and conclusion}

This study examined the differences between TM motives and practices amongst MNEs and local firms in Turkey. The contribution of this paper is two-fold. First, it advances the theoretical understanding of TM. By considering the resource-based view of the firm (RBV) and the various perspectives of institutional theory, the paper shows the limited explanatory power of RBV in determining the motives for TM and the nature of practice. This is particularly pertinent as RBV tends to be the dominant theoretical framework in TM research (Gallardo-Gallardo et al., 2015). Instead, the paper explains how the different perspectives of institutional theory can be used to understand both the motives for TM and its subsequent practice and thus develop a more nuanced appreciation of TM systems. Second, a lacuna exists in our understanding of TM in emerging market economies (Dries, 2013a, Festing et al., 2013, Sidani \& Al Ariss, 2014, Sparrow et al., 2014, Cooke et al., 2014, Farndale et al., 2010) where the retention of talented labour is becoming increasingly difficult (Sparrow et al., 2014). This paper makes a contribution in filling this gap. Turkey provides an interesting backdrop because not only is it considered to be an emerging market economy, but TM is becoming of prime importance to the Turkish economy - driven by growing investments in infrastructure, rising MNE demands for skilled labour, and a shortage of leadership talent (Ali, 2011). Through a comparison of MNE and local firm practice, the paper compared the motives that guide TM implementation and examined the different TM practices between these two organizational groups.

The study shows that MNEs do not differ from their domestic Turkish counterparts with respect to the relative importance of strategic motives for TM. However, MNE subsidiaries do tend to be more tactically orientated than domestic Turkish firms. The study shows that there are differences between local firms and MNEs when it comes to TM practices. MNEs are more likely to use work-based systems, HRM-led systems and international systems. However, MNEs do not differ from their local Turkish counterparts in their use of career portfolio planning. These findings suggest that local Turkish firms are equally as strategic as MNEs when considering their TM motives - TM is focused on the long-term needs of the organization and supports changes in the organization's structure, 
business environment and the achievement of strategic organization goals. This is particularly important as emerging markets have a limited supply of experienced managers (FernandezAraoz et al., 2011) and Turkish institutions emphasise the centrality of TM to economic regeneration and growth (Ali, 2011) which then places an emphasis on building a reputation for talent development in order to gain and circulate talent (Harvey \& Groutsis, 2015). Yet, as stated by Sparrow et al. (2014:20) "for all organizations, talent management was always intended to be about strategy". Therefore, these findings are not particularly surprising as all organizations need to respond to structural and environmental changes and adapt their strategies accordingly. At this point, the RBV logic for TM is weakened. Strategic motives for TM are not focused on the sustainable competitive advantage of the firm, but are focused on profit seeking and responding to and planning for the volatile nature of markets and changing environmental circumstances i.e. demand side influences, that are not captured by the RBV (Kaufman, 2015). Local Turkish firms are impacted by the increasing migration of skilled labour to other parts of Europe and the increasing under-employment of university graduates (Lennard, 2014). In order for these firms to appear attractive, they will need to develop more strategic TM systems akin to those of MNEs. MNEs compete for talent on a global basis and, like their local counterparts, face a shortage of managerial and professional talent (Björkman \& Lervik, 2007, Stahl et al., 2007).

TM is given strategic priority within local Turkish firms despite suggestions that they place less emphasis on the strategic role of the HRM function and embrace fewer performance related people practices overall (Mellahi et al., 2013). This is not a particular concern for some, as TM is far too important to be left solely to HRM managers (Linden \& Teece, 2014, Lawler III, 2008, Fernandez-Araoz et al., 2011). Indeed, Tarique and Schuler (2014) suggest that TM strategy can exist independently of any HRM strategy. As local Turkish firms have different ownership characteristics and tend to be family-owned, the direct link between TM and business strategy is more likely. However, this will impact the nature of practice and the extent to which TM is systematised and embedded within an existing people management architecture. 
While the strategic motives for TM are somewhat normative in nature - based on a Western understanding of what TM should be, the interesting point of departure is the tendency for MNEs to be more tactically oriented than their counterparts. MNEs might have developed systems of TM that are consistent with the macro aspects of the organization, but it would seem that the espousal of a strategic approach emanates at HQ level. A reasonable explanation for this finding is that MNEs initiate TM as a strategic tool, but within the emerging market context, they leverage these tools at a tactical/utilitarian level in order to counteract particular features of the institutional environment. The tenets of TM system design might be developmental and supportive therefore consistent with building and leveraging resources at HQ level, but the actual practice at subsidiary level has more to do with the tactical and operational functioning of the organization, thus any standardisation would appear to have its limits. This is consistent with Hartmann et al. (2010) who found that TM practices were standardised in their sample of China-based MNEs, but these practices were not necessarily internalised. Similarly, Cooke (2010) also researching China-based MNEs, confirms that firms prefer a pragmatic rather than a strategic approach to TM. Lathuka (2014) suggests that MNEs located in Russia tend to have a more mature approach to their TM but it is underdeveloped for the Russian context.

A tactical approach also implies a more decentralised model of TM for these MNEs. Decentralisation therefore indicates that talent is not necessarily moved from one subsidiary to another in order to create competitive advantage and that these subsidiaries are more dependent on the local environment to source talent (Garavan, 2012). Cultural, social and geographic barriers create inefficient global talent systems in MNEs (Minbaeva \& Collings, 2013, Mäkelä et al., 2010) and, as employee behaviours mediate the link between TM and performance (Collings \& Mellahi, 2009, Jiang et al., 2013), a tactical MNE approach will impact psychological contract congruence - employee expectations of TM practices and how they are experienced, and this in turn will impact the performance and reputation of the firm (Martin \& Cerdin, 2014, Sonnenberg et al., 2014). According to Bowman and Hird (2014: 82), generic TM processes are not suitable for every organization as each has a unique context, thus proscribing limits to the explanatory power of RBV. 
Instead, this unique context can be analysed through the lens of sociological institutionalism where organizations are viewed as social entities that seek approval for their performance in socially constructed regulatory, cognitive and normative environments (Scott, 1995). A combination of strategic and tactical TM motives of MNEs demonstrates institutional duality (Edwards \& Ferner, 2004, Kostova \& Roth, 2002) - the former corresponds with the TM motives of HQ and is focussed on coordination and planning and the latter suggests a pressure to respond to idiosyncratic operating contexts. This highlights the importance of social legitimacy, the need for cultural acceptance and a consideration of organization politics (Boxall \& Purcell, 2011, Morgan \& Hauptmeier, 2014), different subsidiary contexts and, to some degree, managerial translation and 'gut feeling' (Burbach \& Royle, 2010, Wiblen et al., 2012).

For both MNEs and local firms TM practice needs to achieve cognitive legitimacy through the adoption of TM systems using external mimetic behaviour as well as internal mimetic behaviour which seeks to conform to old routines and habitual behaviour based on past experience (Yiu \& Makino, 2002). Alongside these mimetic behaviours Vaiman and Brewster (2015) stress that particular features of the economic environment must be considered. Khilji et al. (2015) stress the need to take a macro view of TM and to consider factors such as global mobility, diaspora effects and government policies. Tertiary education in Turkey increased by 324\% between 1990 and 2010 (Lanvin \& Evans, 2014) and Turkey currently represents a buyer's market - with relatively low minimum wages and a surplus of graduates seeking employment (Lennard, 2014). Flexible capacity in the labour market encourages a focus on short term requirements and assumes a more inclusive approach to TM that is able to counteract the effects of a poor education system and poor skills that are characteristic of the country (Çamlıca \& Nibbe, 2014, Lennard, 2014). This, combined with the prevailing management culture within local businesses that is centred on paternalistic, seniority based, high power distance relationships, will shape how strategic and/or tactical motives are then translated into practice.

The study shows that there are differences between local firms and MNEs in the use of TM practices, with MNEs more likely to utilise work-based TM practices, HRM-led systems 
and international systems more than their local counterparts. This suggests a robust and systematic approach to TM shaped by both strategic and tactical motives. Consistent with the concept of institutional duality (Edwards \& Ferner, 2004, Kostova \& Roth, 2002), the combination of HRM-led, international and work-based systems enable a degree of standardisation and adjustment to the potential and actual needs of employees (Vaiman \& Holden, 2011), Further, these standardised systems enable MNEs to embed their corporate cultures (Stahl et al., 2012). The use of more structured practices aligns with the fundamental nature of the MNE but they also exist to indoctrinate and develop social capital within the firm. It must be remembered that MNEs strive to build corporate identity through consistency and those with strong cultures will seek to standardise their practices as much as possible in order to overcome institutional idiosyncrasies at odds with their own culture (Laurent, 1986, Legge, 2005).

In contrast, local firms have a reduced emphasis on HRM-led, work-based and international systems indicative of the poor development of HRM generally in emerging market economies (Budhwar, 2012, Mohamed et al., 2012) yet there were no differences in the extent to which MNEs and local firms utilise career portfolio building (internal and external secondments, job rotation). This implies that for local firms the strategic motives for TM result in practice that is focused on career portfolio building and is less focused on the HRM-led, work-based and international systems. The poor development of the latter is not particularly problematic, given the nature of local Turkish businesses; however, the limited development of more structured practices contradicts the expectation of mimicry and positive spillover effects. These more structured practices appear antithetical to the familial, centralised and collective nature of business in Turkey (Gurbuz \& Mert, 2011, Sayım, 2010, Wasti, 1998). Family firms also tend to have fewer promotion opportunities (Valverde et al., 2013). The emphasis on seniority within Turkish firms suggests a career path that is based upon length of tenure within the organization. Thus, local firms are embedded within their given context and individuals are socialised within this context with rules and norms that guide behaviour. Local firms have the advantage of institution-wide social capital in the form of network intermediaries, a responsive state sector and strong independent business 
associations, as such it could be argued that these organizations have a better understanding of the locus of human value within the Turkish context (Jackson, 2004) and are able to draw from a network of dense and stable relations and shared understanding (Granovetter, 1985:501) which may obviate the need for more complex forms of TM and enable organizations to select the practices that fit their own purpose.

However, institutions comprise of shared patterns of action that lower transaction costs because they predict the actions of others in the same environment (Morgan \& Hauptmeier, 2014). The limited TM emphasis amongst local Turkish firms protects the status quo if we assume high power distance and seniority-based working cultures. More developed TM practice (a combination of systems) fundamentally alters power mechanisms and managerial structures. Skuza et al. (2013:465) concluded that TM endeavours of Polish firms remained stymied by "hallmarks" of the past and a fear that high potentials would threaten their status. In a similar vein, local Turkish firms utilise secondments and job rotation to manage the expectations of talent within the organization and to respond to a tendency for high uncertainty avoidance while protecting existing structures. This reproduction of existing arrangements helps to maintain institutional complementarities including the dependence on a range of government incentives and the ability of certain powerful organizations and entrepreneurs to lobby the state in their favour (Ali, 2011, Elci, 2011). An institutional lens helps to explain the slow pace of change but highlights that change will occur if actors perceive there to be specific benefits or if there are exogenous shocks that force an institutionally consistent response. Thus, the RBV might be the dominant theoretical framework used in the study of TM (Gallardo-Gallardo et al., 2015) but its explanatory power is limited. The motives for TM and the practices that are pursued by organizations are society-bound. The study of TM motives and practices has to be framed within the context of the institution as this shapes the way in which actors perceive and respond to environmental and organizational stimuli and the extent to which they seek to protect the rules that shape and structure their environments. 


\subsection{Implications for practice}

Organizational culture plays a fundamental role in shaping TM motives and practices and the institutions in which these organizations operate limit and shape the extent to which these practices are deemed acceptable. This acceptability will depend upon the evaluation of transactions costs and the extent to which practices adhere to the status quo and facilitate and perpetuate perceptions of a 'stable' environment. However, managers within this environment need to understand the impact their choices have on their ability to attract, develop and retain talented individuals in their organizations. An 'anorexic' and less systematic approach to TM might appease employee concerns about their careers in the short term, but in the long term talented individuals will migrate to other organizations where there is greater scope for recognition and growth. Evidence suggests that Turkish employees respond positively to a range of Western-style HRM practices. Collings et al. (2010a) and Gurbuz and Mert (2011) suggest that in Turkey high road HRM strategies positively impact employee satisfaction. When combined with the threat of global business, the increased uptake of tertiary education, the commensurate increase in the expectations of the quality of work and rewards and Turkey's pace of economic growth, the focus of Turkish managers on career portfolio building through secondments and rotation appears an inadequate system with which to manage these environmental changes. MNEs have developed TM systems that are able to respond to local need and if these Western practices are appreciated by a local workforce then it is incumbent upon Turkish managers to manage careers and talent in a more comprehensive way. This might not be possible for many smaller local firms, however, such firms need to recognise the importance of maintaining and growing their employees, regardless of whether they deploy exclusive or inclusive TM practices. The protection of traditional job design, organization and managerial structure will limit the attractiveness of local employers in the long term. While Turkish firms might not need to develop more tactical motives for TM, TM is substantially more than career portfolio planning. There is a need for managers to question their practice and the assumptions upon which these are based. This requires reflexivity and a degree of objectivity in order to recognise the role of power relationships, the nature of primary cultural drivers, how these shape practice and job design, 
and the impact that each of these has on qualitative and quantitative talent performance indicators.

\subsection{Limitations and further research}

The study makes a valuable contribution to research in the emerging field of TM and examines the TM phenomenon within an emerging market context; however, as with most studies it is not without its limitations. The TM variables in the study are aligned to the prescriptions of the CIPD and therefore Western notions of what should be considered TM practice. While this is not problematic when seeking to identify the extent to which Western best practice is converging elsewhere, there is a need to examine whether there is a culturally specific and relevant meaning to TM amongst Turkish managers and then to further assess whether these meanings are consistent with practice. These meanings and practices can then be compared to the MNE population. Equally, the nationality of the MNE needs to be considered more closely in order to understand the more nuanced differences between MNEs - this would help to develop a more robust analysis of how TM is perceived across nationalities and the extent to which these perceptions are being shaped by TM discourse.

Given the differences in TM motives and practices discussed in this paper, and the division of opinion that exists within the extant literature on the role the HRM function should play in the design and implementation of TM, future studies should examine the way in which talent decisions are made and the extent to which the HRM function plays a role. Future studies should also consider how and whether TM systems are linked to a robust HRM strategy and whether an HRM strategy makes any difference to the outcomes of a TM system. The notion of reverse diffusion also presents an interesting opportunity for further research, in particular the question of how MNEs develop their practice, if we are to assume global mobility, and to what extent MNEs borrow from other institutional contexts to create more hybridised forms of TM that have more universal appeal. 


\section{References}

AL ARISS, A., CASCIO, W. F. \& PAAUWE, J. 2014. Talent management: Current theories and future research directions. Journal of World Business, 49, 173-179.

ALI, A. J. 2011. Talent Management in the Middle East. In: SCULLION, H. \& COLLINGS, D. (eds.) Global Talent Management. Abindgdon: Routledge.

ASHTON, D., BROWN, P. \& LAUDER, H. 2010. Skill webs and international human resource management: lessons from a study of the global skill strategies of transnational companies. The International Journal of Human Resource Management, $21,836-850$.

BARNEY, J. 1991. Firm Resources and Sustained Competitive Advantage. Journal of Management, 17, 99-129.

BARNEY, J. 2002. Gaining and Sustaining Competitive Advantage, New Jersey, Pearson Education.

BARTLETT, C., GHOSHAL, S. \& BIRKINSHAW, J. 2003. Transational Management: Texts, Cases and Readings in Cross-Border Management, Singapore, McGraw Hill.

BECKER, B. E. \& HUSELID, M. A. 2006. Strategic Human Resources Management: Where Do We Go From Here? Journal of Management, 32, 898-925.

BEECHLER, S. \& WOODWARD, I. 2009. The global "war for talent". Journal of International Management, 15, 273-285.

BEULEN, E. 2009. The contribution of a global service provider's Human Resources Information System (HRIS) to staff retention in emerging markets: Comparing issues and implications in six developing countries. Information Technology \& People, 22, 270-288.

BJÖRKMAN, I., EHRNROOTH, M., MÄKELÄ, K., SMALE, A. \& SUMELIUS, J. 2013. Talent or not? Employee reactions to talent identification. Human Resource Management, 52, 195-214.

BJÖRKMAN, I. \& LERVIK, J. E. 2007. Transferring HR practices within multinational corporations. Human Resource Management Journal, 17, 320-335.

BOWMAN, C. \& HIRD, M. 2014. A resource-based view of talent management. In: SPARROW, P., SCULLION, H. \& TARIQUE, I. (eds.) Strategic Talent Management: Contemporary Issues in International Context. Cambridge: Cambridge University Press.

BOXALL, P. \& PURCELL, J. 2011. Strategy and Human Resource Management, Basingstoke, Palgrave Macmillan.

BOZKURT, Ö. \& MOHR, A. T. 2011a. Forms of cross-border mobility and social capital in multinational enterprises. Human Resource Management Journal, 21, 138-155.

BOZKURT, Ö. \& MOHR, A. T. 2011b. Forms of cross-border mobility and social capital in multinational enterprises. Human Resource Management Journal, 21, 138-155.

BÜCKER, J. 2014. Cultural Intelligence as a Key Construct for Global Talent Management. In: AL ARISS, A. (ed.) Global Talent Management. London: Springer.

BUDHWAR, P. 2012. Management of human resources in foreign firms operating in India: the role of HR in country-specific headquarters. The International Journal of Human Resource Management, 23, 2514-2531.

BURBACH, R. \& ROYLE, T. 2010. Talent on demand? Talent management in the German and Irish subsidiaries of a US multinational corporation. Personnel Review, 39, 414431.

ÇAMLıCA, M. \& NIBBE, J. 2014. Ernst and Young's Attractiveness Survey:Turkey 2013 the shift, the growth and the promise [Online]. UK: Ernst and Young. Available: http://www.ey.com/Publication/vwLUAssets/Turkey_attractiveness_survey_2013/\$FI LE/turkey_attractiveness_2013.pdf [Accessed 19th January 2015]. 
CAPPELLI, P. 2008. Talent Management for the Twenty-First Century. Harvard Business Review, March 2008, 74-81.

CERDIN, J.-L. \& BREWSTER, C. 2014. Talent management and expatriation: Bridging two streams of research and practice. Journal of World Business, 49, 245-252.

CHABAUlT, D., HULIN, A. \& SOPARNOT, R. 2012. Talent management in clusters. Organizational Dynamics, , 41, 327-335.

CHADEE, D. \& RAMAN, R. 2012. External knowledge and performance of offshore IT service providers in India: the mediating role of talent management. Asia Pacific Journal of Human Resources, 50, 459-482.

CIPD 2011. Learning and Talent Development Annual Survey Report. CIPD: London.

CIPD 2012. Learning and Talent Development Annual Survey Report. CIPD: London.

COLLINGS, D. G. 2014. Integrating global mobility and global talent management: Exploring the challenges and strategic opportunities. Journal of World Business, 49, 253-261.

COLlingS, D. G., DEMIRBAG, M., MELlAhI, K. \& TATOGLU, E. 2010a. Strategic orientation, human resource management practices and organizational outcomes: evidence from Turkey. The International Journal of Human Resource Management, 21, 2589-2613.

COLLINGS, D. G., MCDONNELL, A., GUNNIGLE, P. \& LAVELLE, J. 2010b. Swimming Against the Tide: Outward Staffing Flows from Multinational Subsidiairies. Human Resource Management, 49, 575-598.

COLLINGS, D. G. \& MELLAHI, K. 2009. Strategic talent management: A review and research agenda. Human Resource Management Review, 19, 304-313.

COLLINGS, D. G. \& MELLAHI, K. 2013. Commentary on:“Talent—Innate or acquired? Theoretical considerations and their implications for talent management". Human Resource Management Review, 23, 322-325.

COLLINGS, D. G. \& SCULLION, H. 2012. Global Staffing: A Critical Review. In: STAHL, G. K. \& BJÖRKMAN, I. (eds.) Handbook of International Human Resource Management. London: Edward Elgar Publishing.

COLLINGS, D. G., SCULLION, H. \& MORLEY, M. J. 2007. Changing patterns of global staffing in the multinational enterprise: Challenges to the conventional expatriate assignment and emerging alternatives. Journal of World Business, 42, 198-213.

COOKE, F. 2010. Talent Management in China. In: SCULliON, H. \& COLLINGS, D. (eds.) Global Talent Management. Abingdon: Routledge.

COOKE, F. L., SAINI, D. S. \& WANG, J. 2014. Talent management in China and India: A comparison of management perceptions and human resource practices. Journal of World Business, 49, 225-235.

CRANFIELD UNIVERSITY 2003. CRANET Survey. Cranfield: Cranfield University.

CRANFIELD UNIVERSITY 2006. CRANET survey on Comparative Human Resource Management. International Executive Report. Bedford: Cranfield University,.

DELONG, T. J. \& VIJAYARAGHAVAN, V. 2003. Let's hear it for B players. Harvard Business Review, 81, 96-102, 137.

DEMIRBAG, M., TATOGLU, E. \& WILKINSON, A. 2015. Adoption of High-Performance Work Systems by Local Subsidiaries of Developed Country and Turkish MNEs and Indigenous Firms in Turkey. Human Resource Management.

DEMIRBAG, M., COLlingS, D.G., TATOGLU, E., MELlAHI, K., \& WOOD, G. 2014. High-Performance Work Systems and Organizational Performance in Emerging Economies: Evidence from MNEs in Turkey, Management International Review, 54:325-359. 
DIMAGGIO, P. \& POWELL, W. 1983. The Iron Cage Revisited - Institutional Isomorphism And Collective Rationality In Organisational Fields. In: POWELL, W. \& DIMAGGIO, P. (eds.) The New Institutionalism In Organisational Analysis. Chicago: Chicago University Press.

DOH, J. P., SMITH, R., STUMPF, S. A. \& TYMON JR, W. G. 2014. Emerging markets and regional patterns in talent management: the challenge of India and China. In: SPARROW, P., SCULLION, H. \& TARIQUE, I. (eds.) Strategic Talent Management: Contemporary Issues in International Context. Cambridge: Cambridge University Press.

DOH, J. P., TYMON JR, W. G. \& STUMPF, S. A. 2010. Talent Management in India. In: SCULliON, H. \& COLliNGS, D. (eds.) Global Talent Management. Abingdon: Routledge.

DRIES, N. 2013a. The psychology of talent management: A review and research agenda. Human Resource Management Review, 23, 272-285.

DRIES, N. 2013b. Talent Management, from phenomenon to theory: Introduction to the Special Issue. Human Resource Management Review, 23, 267-271.

EDWARDS, T. \& FERNER, A. 2004. Multinationals, reverse diffusion and national business systems. Management International Review. Springer.

ELCI, S. 2011. Leveraging Training. Skills Development in SMEs. AN ANALYSIS OF OSTIM ORGANISED INDUSTRIAL ZONE [Online]. Available: http://www.oecd.org/cfe/leed/49180428.pdf [Accessed 19th January 2015].

ERCEK, M. 2006. HRMization in Turkey: expanding the rhetoric-reality debate in space and time. The International Journal of Human Resource Management, 17, 648-672.

EUROMONITOR. 2014. Is Turkey Losing its Appeal for Investors? [Online]. Euromonitor. Available:

http://0www.portal.euromonitor.com.pugwash.lib.warwick.ac.uk/Portal/Pages/Magazine/Top icPage.aspx [Accessed 1st June 2014].

FARNDALE, E., PAI, A., SPARROW, P. \& SCULLION, H. 2014. Balancing individual and organizational goals in global talent management: A mutual-benefits perspective. Journal of World Business, 49, 204-214.

FARNDALE, E., SCULLION, H. \& SPARROW, P. 2010. The role of the corporate HR function in global talent management. Journal of World Business, 45, 161-168.

FERNANDEZ-ARAOZ, C., GROYSBERG, B. \& NOHRIA, N. 2011. How to Hang On to Your High Potentials. Emerging Best Practices in Managing Your Company's Future Leaders. Harvard Business Review, 76-83.

FESTING, M., SCHÄFER, L. \& SCULLION, H. 2013. Talent management in medium-sized German companies: an explorative study and agenda for future research. The International Journal of Human Resource Management, 24, 1872-1893.

GALLARDO-GALLARDO, E., DRIES, N. \& GONZÁLEZ-CRUZ, T. F. 2013. What is the meaning of 'talent' in the world of work? Human Resource Management Review, 23, 290-300.

GALlARDO-GALlARDO, E., NIJS, S., DRIES, N. \& GALlO, P. 2015. Towards an understanding of talent management as a phenomenon-driven field using bibliometric and content analysis. Human Resource Management Review, 25, 264-279.

GARAVAN, T. N. 2012. Global talent management in science-based firms: an exploratory investigation of the pharmaceutical industry during the global downturn. The International Journal of Human Resource Management, 23, 2428-2449.

GARVER, M. S. \& MENTZER, J. T. 1999. Logistics research methods: employing structural equation modeling to test for construct validity. Journal of Business Logistics, 20, 3358. 
GELENS, J., HOFMANS, J., DRIES, N. \& PEPERMANS, R. 2014. Talent management and organisational justice: employee reactions to high potential identification. Human Resource Management Journal, n/a-n/a.

GLAISTER, K. W., DINCER, O., TATOGLU, E., DEMIRBAG, M. \& ZAIM, S. 2008. A causal analysis of formal strategic planning and firm performance: evidence from an emerging country. Management Decision, 46, 365-391.

GRANOVETTER, M. 1985. Economic Action and Social Structure: The Problem of Embededness. American Journal of Sociology, 91, 481-510.

GROYSBERG, B. 2012. Chasing stars: The myth of talent and the portability of performance, Princeton University Press.

GURBUZ, S. \& MERT, I. S. 2011. Impact of the strategic human resource management on organizational performance: evidence from Turkey. The International Journal of Human Resource Management, 22, 1803-1822.

GUTHRIDGE, M., KOMM, A. \& LAWSON, E. 2008. Making talent a strategic priority. McKinsey Quarterly, 4.

HARTMANN, E., FEISEL, E. \& SCHOBER, H. 2010. Talent management of western MNCs in China: Balancing global integration and local responsiveness. Journal of World Business, 45, 169-178.

HARVEY, W. S. \& GROUTSIS, D. 2015. Reputation and talent mobility in the Asia Pacific. Asia Pacific Journal of Human Resources, 53, 22-40.

HILTROP, J.-M. 1999. The quest for the best: human resource practices to attract and retain talent. European Management Journal, 17, 422-430.

HORWITZ, F. M. 2012. Evolving human resource management in Southern African multinational firms: towards an Afro-Asian nexus. The International Journal of Human Resource Management, 23, 2938-2958.

HUANG, J. \& TANSLEY, C. 2012. Sneaking through the minefield of talent management: the notion of rhetorical obfuscation. The International Journal of Human Resource Management, 23, 3673-3691.

HUANG, T. 2000. Human Resource Management Practices at Subsidiaries of Multinational Corporations and Local Firms in Taiwan. International Journal of Selection and Assessment, 8, 22-28.

ILES, P. 2013. Commentary on "The meaning of 'talent'in the world of work". Human Resource Management Review, 23, 301-304.

ILLES, P., CHUAI, X. \& PREECE, D. 2010. Talent Management and HRM in Multinational Companies in Beijing: Definitions, Differences and Drivers. Journal of Business Research, 45, 179-189.

JACKSON, T. 2004. International HRM - A Cross Cultural Approach. London: Sage Publications.

JIANG, K., TAKEUCHI, R. \& LEPAK, D. P. 2013. Where do We Go From Here? New Perspectives on the Black Box in Strategic Human Resource Management Research. Journal of Management Studies, 50, 1448-1480.

JOYCE, W. F. \& SLOCUM, J. W. 2012. Top management talent, strategic capabilities, and firm performance. Organizational Dynamics, 41, 183-193.

KABASAKAL, H. \& DASTMALCHIAN, A. 2001. Introduction to the special issue on leadership and culture in the Middle East. Applied Psychology: An International Review, 50, 479-488.

KAYA, N. 2006. The impact of human resource management practices and corporate entrepreneurship on firm performance: evidence from Turkish firms. The International Journal of Human Resource Management, 17, 2074-2090. 
KELEŞ, S. \& AYCAN, Z. 2011. The relationship of managerial values and assumptions with performance management in Turkey: understanding within culture variability. The International Journal of Human Resource Management, 22, 3080-3096.

KHILJI, S. E., TARIQUE, I. \& SCHULER, R. S. 2015. Incorporating the macro view in global talent management. Human Resource Management Review, 25, 236-248.

KIM, S., FROESE, F. J. \& COX, A. 2012. Applicant attraction to foreign companies: the case of Japanese companies in Vietnam. Asia Pacific Journal of Human Resources, $50,439-458$.

KOSTOVA, T. \& ROTH, K. 2002. Adoption of an organizational practice by subsidiaries of multinational corporations: Institutional and relational effects. Academy of Management Journal, 45, 215-233.

LANVIN, B. \& EVANS, P. 2014. Global Talent Competitiveness Index 2014. Singapore: INSEAD.

LATUKHA, M. 2014. Talent management in Russian companies: domestic challenges and international experience. The International Journal of Human Resource Management, 26, 1051-1075.

LAURENT, A. 1986. The Cross Cultural Puzzle Of International Human Resource Management. Human Resource Management, 25, 91-102.

LAWLER III, E. 2008. Talent. Making People Your Competitive Advantage, San Francisco, Jossey Bass.

LEGGE, K. 2005. Human Resource Management Rhetorics and Realities, Basingstoke, Hampshire, Palgrave Macmillan.

LENNARD, C. 2014. Business Environment: Turkey [Online]. Euromonitor. Available: www.portal.euromonitor.com/portal.analysis/tab [Accessed 19 January 2015].

LEPAK, D. \& SNELL, S. 1999. The Human Resource Architecture: Toward a Theory of Human Capial Allocation and Development. The Academy of Management Review, 24, 31-48.

LEWIS, A. 2009. HR Outsourcing and the HR Function: Threat or Opportunity. London: Chartered Insitute of Personnel and Development.

LEWIS, R. E. \& HECKMANN, R. J. 2006. Talent Managment: A Critical Review. Human Resource Management Review, 16, 139-154.

LINDEN, G. \& TEECE, D. 2014. Managing Expert Talent. In: SPARROW, P., SCULLION, H. \& TARIQUE, I. (eds.) Strategic Talent Management: Contemporary Issues in International Context. Cambridge: Cambridge University Press.

LOSEY, M., MEISINGER, S. \& ULRICH, D. 2005. The Future of Human Resource Management, Hoboken, New Jersey, John Wiley and Sons.

MÄKELÄ, K., BJÖRKMAN, I. \& EHRNROOTH, M. 2010. How do MNCs establish their talent pools? Influences on individuals' likelihood of being labeled as talent. Journal of World Business, 45, 134-142.

MARTIN, G. \& CERDIN, J.-L. 2014. Employer branding and career theory: new directions for research In: SPARROW, P., SCULLION, H. \& TARIQUE, I. (eds.) Strategic Talent Management: Contemporary Issues in International Context. Cambridge: Cambridge University Press.

MARTINEZ, R. \& DACIN, M. 1999. Efficiency Motives and Normative Forces: Combining Transaction Costs and Institutional Logic. Journal of Management, 25, 75-96.

MCCARTNEY, C. 2010. Fighting Back Through Talent Innovation: Talent Managment Under Threat in Uncertain Times. In: CIPD (ed.). London: CIPD.

MCDONNELL, A., LAMARE, R., GUNNIGLE, P. \& LAVELLE, J. 2010. Developing tomorrow's leaders-Evidence of global talent management in multinational enterprises. Journal of World Business, 45, 150-160. 
MCEVILY, B. \& ZAHEER, A. 1999. BRIDGING TIES: A SOURCE OF FIRM HETEROGENEITY IN COMPETITIVE CAPABILITIES. Strategic Management Journal, 20, 1133-1156.

MCWILLIAMS, A., VAN FLEET, D. D. \& WRIGHT, P. M. 2001. Strategic management of human resources for global competitive advantage. Journal of Business Strategies, 18, $1-24$.

MELLAHI, K. \& COLLINGS, D. G. 2010. The barriers to effective global talent management: The example of corporate élites in MNEs. Journal of World Business, 45, 143-149.

MELlAHI, K., DEMIRBAG, M., COLlingS, D. G., TATOGLU, E. \& HUGHES, M. 2013. Similarly different: a comparison of HRM practices in MNE subsidiaries and local firms in Turkey. The International Journal of Human Resource Management, 24, 2339-2368.

MENTZER, J. T. \& FLINT, D. J. 1997. Validity in logistics research. Journal of Business Logistics, 18, 199-216.

MEYERS, M. C. \& VAN WOERKOM, M. 2014. The influence of underlying philosophies on talent management: Theory, implications for practice, and research agenda. Journal of World Business, 49, 192-203.

MEYERS, M. C., VAN WOERKOM, M. \& DRIES, N. 2013. Talent - Innate or acquired? Theoretical considerations and their implications for talent management. Human Resource Management Review, 23, 305-321.

MEYSKENS, M., VON GLINOW, M. A., WERTHER, J. W. B. \& CLARKE, L. 2009. The paradox of international talent: alternative forms of international assignments. The International Journal of Human Resource Management, 20, 1439-1450.

MINBAEVA, D. \& COLLINGS, D. G. 2013. Seven myths of global talent management. The International Journal of Human Resource Management, 24, 1762-1776.

MOHAMED, A. F., SINGH, S., IRANI, Z. \& DARWISH, T. K. 2012. An analysis of recruitment, training and retention practices in domestic and multinational enterprises in the country of Brunei Darussalam. The International Journal of Human Resource Management, 1-27.

MORGAN, G. \& HAUPTMEIER, M. 2014. Institutional Theory in Comparative Employment Relations. In: WILKINSON, A., WOOD, G. \& DEEG, R. (eds.) The Oxford Handbook of Employment Relations. Oxford: Oxford University Press.

MYLONI, B., HARZING, A. W. \& MIRZA, H. 2004. Human Resource Management in Greece: Have the Colours of Culture Faded Away? International Journal of Cross Cultural Management, 4, 59-76.

NALBANTIAN, H. R. \& GUZZO, R. A. 2009. Making Mobility Matter. Harvard Business Review, 87, 76-84.

NIJS, S., GALLARDO-GALLARDO, E., DRIES, N. \& SELS, L. 2014. A multidisciplinary review into the definition, operationalization, and measurement of talent. Journal of World Business, 49, 180-191.

OECD 2012. Country statistical profile: Turkey 2011.

OLIVER, C. 1997. SUSTAINABLE COMPETITIVE ADVANTAGE: COMBINING INSTITUTIONAL AND RESOURCE-BASED VIEWS. Strategic Management Journal, 18, 697-713.

ORTLIEB, R. \& SIEBEN, B. 2011. How to safeguard critical resources of professional and managerial staff: exploration of a taxonomy of resource retention strategies. The International Journal of Human Resource Management, 23, 1688-1704.

PAAUWE, J. \& BOSELIE, P. 2003. Challenging 'strategic HRM' and the relevance of the institutional setting. Human Resource Management Journal, 13, 56-70. 
PELSTER, B., SCHWARTZ, J., RIZZO, D., VALENZUELA, J. \& VAN DER VYER, B. 2013. The War to Develop Talent. Deloitte Consulting, Resetting Horizons - Human Capital Trends 2013.

PERLMUTTER, H. 1969. The Tortuous Evolution of the Multinational Corporation. Columbia Journal of World Business, 4, 9-18.

PETERAF, M. 1993. The Cornerstones of Competitive Advantage: A Resource-Based View. Strategic Management Journal, 14, 179-191.

RUBERY, J. \& GRIMSHAW, D. 2003. The Organization of Employment: An International Perspective, Basingstoke, Hampshire, Palgrave Macmillan.

SAINI, D. \& BUDHWAR, P. 2004. Human Resource Management in India. In: BUDHWAR, P. (ed.) Managing Human Resources in the Asia Pacific. London: Routledge.

SAY1M, K. Z. 2010. Pushed or pulled? Transfer of reward management policies in MNCs. The International Journal of Human Resource Management, 21, 2631-2658.

SCHIEMANN, W. A. 2014. From talent management to talent optimization. Journal of World Business, 49, 281-288.

SCOTT, W. R. 1987. The adolescence of institutional theory. Administrative Science Quarterly, 493-511.

SCOTT, W. R. 1995. Institutions and organizations, Sage Thousand Oaks, CA.

SCULLION, H. \& COLLINGS, D. 2010. Global Talent Management, Routledge.

SIDANI, Y. \& AL ARISS, A. 2014. Institutional and corporate drivers of global talent management: Evidence from the Arab Gulf region. Journal of World Business, 49, 215-224.

SKUZA, A., SCULLION, H. \& MCDONNELL, A. 2013. An analysis of the talent management challenges in a post-communist country: the case of Poland. The International Journal of Human Resource Management, 24, 453-470.

SONNENBERG, M., VAN ZIJDERVELD, V. \& BRINKS, M. 2014. The role of talentperception incongruence in effective talent management. Journal of World Business, 49, 272-280.

SPARROW, P., FARNDALE, E. \& SCULLION, H. 2013. An empirical study of the role of the corporate HR function in global talent management in professional and financial service firms in the global financial crisis. The International Journal of Human Resource Management, 24, 1777-1798.

SPARROW, P. \& MAKRAM, H. 2015. What is the value of talent managment? Building value-driven Human Resource Management Review, Article in Press.

SPARROW, P., SCULLION, H. \& TARIQUE, I. (eds.) 2014. Strategic Talent Management: Contemporary Issues in International Context, Cambridge: Cambridge University Press.

STAHL, G., BJORKMAN, I., FARNDALE, E., MORRIS, S. S., PAAUWE, J. \& STILES, P. 2012. Six Principles of Effective Global Talent Management. MIT Sloan Management Review, 53, 25-32.

STAHL, G. K., BJORKMAN, I., FARNDALE, E., MORRIS, S., PAAUWE, J., STILES, P., TREVOR, J. \& WRIGHT, P. 2007. Global talent management: How leading multinationals build and sustain their talent pipeline. INSEAD Faculty and Research Working Papers, 24.

STEINMO, S., THELEN, K. A. \& LONGSTRETH, F. 1992. Structuring Politics: Historical Institutionalism in Comparative Analysis, Cambridge, Cambridge University Press.

TAN, D. \& MAHONEY, J. T. 2003. Explaining the utilization of managerial expatriates from the perspectives of resource-based, agency, and transaction-costs theories. Advances in international management, 15, 179-205. 
TARIQUE, I. \& SCHULER, R. 2010. Global talent management: Literature review, integrative framework, and suggestions for further research. Journal of World Business, 45, 122-133.

TARIQUE, I. \& SCHULER, R. 2014. A typology of talent-management strategies. In: SPARROW, P., SCULLION, H. \& TARIQUE, I. (eds.) Strategic Talent Management: Contermporary Issues in International Context. Cambridge: Cambridge University Press.

TATLI, A., VASSILOPOULOU, J. \& ÖZBILGIN, M. 2013. An unrequited affinity between talent shortages and untapped female potential: The relevance of gender quotas for talent management in high growth potential economies of the Asia Pacific region. International Business Review, 22, 539-553.

TEAGARDEN, M., MEYER, I. \& JONES, D. 2008. Knowledge Sharing among Hi-Tech MNCs in China and India: Invisible Barriers, Best Practices and Next Steps. Organizational Dynamics, 37, 190-202.

TEMPEST, S., MCKINLAY, A. \& STARKEY, K. 2004. Careering alone: Careers and social capital in the financial services and television industries. Human Relations, 57, 15231545.

THUNNISSEN, M., BOSELIE, P. \& FRUYTIER, B. 2013. A review of talent management: 'infancy or adolescence?'. The International Journal of Human Resource Management, 24, 1744-1761.

TÜZÜNER, L. 2014. Human resource management in Turkey. In: KAUFMAN, B. E. (ed.) The Development of Human Resource Management Across Nations: Unity and Diversity. Cheltenham: Edward Elgar Publishing Ltd.

TÜZÜNER, L., GUROL, Y. D. \& MUHTESEM, B. 2014. Current Human Resource Management Practices in Turkey. International Conference on Business, Economices,Marketing and Management Research. Sousse, Tunisia: Economics \& Strategic Management of Business Process.

UZZI, B. 1996. The sources and consequences of embeddedness for the economic performance of organizations: The network effect. American Sociological Review, 61, August 674-698.

VAIMAN, V. \& BREWSTER, C. 2015. How far do cultural differences explain the differences between nations? Implications for HRM. The International Journal of Human Resource Management, 26, 151-164.

VAIMAN, V. \& COLLINGS, D. G. 2013. Talent management: advancing the field. The International Journal of Human Resource Management, 24, 1737-1743.

VAIMAN, V. \& HOLDEN, N. 2011. Talent Management in Central and Eastern Europe. In: SCULliON, H. \& COLlingS, D. (eds.) Global Talent Management. Abingdon: Taylor and Francis.

VALVERDE, M., SCULLION, H. \& RYAN, G. 2013. Talent management in Spanish medium-sized organisations. The International Journal of Human Resource Management, 24, 1832-1852.

WASTI, S. A. 1998. Cultural barriers in the transferability of Japanese and American human resources practices to developing countries: the Turkish case. The International Journal of Human Resource Management, 9, 608-631.

WIBLEN, S., DERY, K. \& GRANT, D. 2012. Do you see what I see? The role of technology in talent identification. Asia Pacific Journal of Human Resources, 50, 421-438.

WICKRAMASINGHE, V. \& WELIWITIGODA, P. 2011. Benefits gained from dimensions of social capital: a study of software developers in Sri Lanka. Information Technology \& People, 24, 393-413. 
WÖCKE, A., BENDIXEN, M. \& RIJAMAMPIANINA, R. 2007. Building flexibility into multi-national human resource strategy: a study of four South African multi-national enterprises. The International Journal of Human Resource Management, 18, 829-844.

YIU, D. \& MAKINO, S. 2002. The Choice Between Joint Venture and Wholly Owned Subsidiary: An Institutional Perspective. Organization Science, 13, 667-683. 
Table 1. Characteristics of questionnaire respondent firms

\begin{tabular}{|c|c|c|c|c|c|}
\hline \multirow[t]{2}{*}{ Characteristic } & & \multicolumn{2}{|c|}{ Turkish firms } & \multicolumn{2}{|c|}{ MNE subsidiaries } \\
\hline & & Number & $\%$ & Number & $\%$ \\
\hline \multirow[t]{2}{*}{$\begin{array}{l}\text { Respondent } \\
\text { type }\end{array}$} & $\begin{array}{l}\text { Upper level (e.g., CEO, chairman, board } \\
\text { member and deputy GM ) }\end{array}$ & 58 & 46.0 & 28 & 37.3 \\
\hline & $\begin{array}{l}\text { Medium level (department head and } \\
\text { director) }\end{array}$ & 68 & 54.0 & 47 & 62.7 \\
\hline \multirow{3}{*}{$\begin{array}{l}\text { Functional } \\
\text { area }\end{array}$} & General management & 51 & 40.5 & 22 & 29.3 \\
\hline & HRM & 63 & 50.0 & 49 & 65.3 \\
\hline & Administration & 12 & 9.5 & 4 & 5.4 \\
\hline \multirow[t]{11}{*}{$\begin{array}{l}\text { Industry } \\
\text { sector }\end{array}$} & $\begin{array}{l}\text { Industrial, automotive and electrical } \\
\text { equipments }\end{array}$ & 11 & 8.7 & 11 & 14.7 \\
\hline & Textile and apparel & 20 & 15.9 & 4 & 5.3 \\
\hline & Food, beverage and paper & 7 & 5.6 & 8 & 10.7 \\
\hline & Metal, wood, leather and glass & 16 & 12.7 & 2 & 2.7 \\
\hline & Chemical and pharmaceuticals & 3 & 2.4 & 5 & 6.7 \\
\hline & Other manufacturing & 16 & 12.6 & 4 & 5.3 \\
\hline & Wholesale and retail trade & 18 & 14.3 & 2 & 2.7 \\
\hline & Computer and engineering services & 5 & 4.0 & 5 & 6.7 \\
\hline & Financial services and consultancy & 7 & 5.6 & 14 & 18.6 \\
\hline & Hospitality and leisure services & 10 & 7.9 & 4 & 5.3 \\
\hline & Other services & 13 & 10.3 & 16 & 21.3 \\
\hline \multirow{5}{*}{$\begin{array}{l}\text { Number of } \\
\text { employees }\end{array}$} & Less than 250 & 62 & 49.2 & 15 & 20.0 \\
\hline & $251-500$ & 23 & 18.3 & 16 & 21.3 \\
\hline & $501-1000$ & 24 & 19.0 & 8 & 10.7 \\
\hline & $1001-5000$ & 14 & 11.1 & 23 & 30.7 \\
\hline & More than 5000 & 3 & 2.4 & 13 & 17.3 \\
\hline $\begin{array}{l}\text { Years of } \\
\text { operation }\end{array}$ & Mean & \multicolumn{2}{|c|}{23.60} & \multicolumn{2}{|c|}{26.22} \\
\hline & $N$ & \multicolumn{2}{|c|}{126} & \multicolumn{2}{|c|}{75} \\
\hline
\end{tabular}


Table 2. EFA of TM motives

\begin{tabular}{|c|c|c|c|c|c|}
\hline Factors & $\begin{array}{l}\text { Factor } \\
\text { loads }\end{array}$ & $\begin{array}{l}\text { Eigen- } \\
\text { value }\end{array}$ & $\begin{array}{l}\text { \% Variance } \\
\text { explained }\end{array}$ & $\begin{array}{c}\text { Cum. } \\
\text { per cent }\end{array}$ & $\begin{array}{l}\text { Cronbach } \\
\text { alpha }\end{array}$ \\
\hline Factor 1: & & 3.93 & 39.33 & 39.33 & 0.85 \\
\hline Strategically orientated (TMM1) & & & & & \\
\hline To support changes in the organization's structure & 0.89 & & & & \\
\hline $\begin{array}{l}\text { To support changes in the organization's business } \\
\text { environment }\end{array}$ & 0.85 & & & & \\
\hline To assist the organization's workforce planning & 0.73 & & & & \\
\hline To enable achievement of the organization's strategic goals & 0.55 & & & & \\
\hline $\begin{array}{l}\text { Factor } 2: \\
\text { Tactically orientated (TMM2) }\end{array}$ & & 2.45 & 24.46 & 63.79 & 0.83 \\
\hline To grow future strong leaders & 0.79 & & & & \\
\hline To retain key staff & 0.76 & & & & \\
\hline To address skill shortages & 0.69 & & & & \\
\hline To attract key staff to the organization & 0.64 & & & & \\
\hline To meet future skill requirements & 0.61 & & & & \\
\hline To redeploy staff to other roles & 0.54 & & & & \\
\hline
\end{tabular}

K-M-O Measure of Sampling Adequacy $=0.863 ;$ Bartlett Test of Sphericity $=1009.09 ; p<0.000$.

Table 3. EFA of TM practices

\begin{tabular}{|c|c|c|c|c|c|}
\hline Factors & $\begin{array}{l}\text { Factor } \\
\text { loads }\end{array}$ & $\begin{array}{l}\text { Eigen- } \\
\text { value }\end{array}$ & $\begin{array}{l}\% \text { Variance } \\
\text { explained }\end{array}$ & $\begin{array}{c}\text { Cum. } \\
\text { per cent }\end{array}$ & $\begin{array}{l}\text { Cronbach } \\
\text { alpha }\end{array}$ \\
\hline $\begin{array}{l}\text { Factor 1: } \\
\text { Work-based systems (TMP1) }\end{array}$ & & 4.35 & 21.77 & 21.77 & 0.91 \\
\hline Networking & 0.81 & & & & \\
\hline Internal project teams & 0.78 & & & & \\
\hline Special tasks to stimulate learning & 0.73 & & & & \\
\hline In-house development programs & 0.66 & & & & \\
\hline Cross disciplinary project working & 0.61 & & & & \\
\hline Instructor-led off the job training & 0.60 & & & & \\
\hline Formal career plans & 0.57 & & & & \\
\hline $\begin{array}{l}\text { Factor 2: } \\
\text { HRM-led systems (TMP2) }\end{array}$ & & 3.96 & 19.79 & 41.56 & 0.90 \\
\hline Coaching & 0.79 & & & & \\
\hline Mentoring & 0.77 & & & & \\
\hline Assessment centres & 0.68 & & & & \\
\hline Graduate development programs & 0.55 & & & & \\
\hline Succession plans & 0.53 & & & & \\
\hline High flier schemes & 0.53 & & & & \\
\hline University courses & 0.51 & & & & \\
\hline $\begin{array}{l}\text { Factor 3: } \\
\text { International systems (TMP3) }\end{array}$ & & 3.48 & 17.42 & 58.98 & 0.94 \\
\hline Training in international operations & 0.86 & & & & \\
\hline Short term international systems ( $<12$ months) & 0.82 & & & & \\
\hline International project teams & 0.79 & & & & \\
\hline
\end{tabular}




\begin{tabular}{|c|c|c|c|c|}
\hline $\begin{array}{l}\text { Factor 4: } \\
\text { Career portfolio building (TMP4) }\end{array}$ & 2.75 & 13.73 & 72.71 & 0.77 \\
\hline Internal secondment & 0.81 & & & \\
\hline Job rotation & 0.69 & & & \\
\hline External secondments & 0.68 & & & \\
\hline
\end{tabular}

K-M-O Measure of Sampling Adequacy $=0.914$; Bartlett Test of Sphericity $=2836.39 ; p<0.000$.

Table 4. CFA of TM motives

\begin{tabular}{lc}
\hline Factors & Standardized regression weight* \\
\hline Strategically orientated (TMM1) & \\
To support changes in the organization's structure & 0.74 \\
To support changes in the organization's business environment & 0.64 \\
To assist the organization's workforce planning & 0.77 \\
To enable achievement of the organization's strategic goals & 0.70 \\
\hline Tactically orientated (TMM2) & \\
To grow future strong leaders & 0.50 \\
To retain key staff & 0.52 \\
To address skill shortages & 0.81 \\
To attract key staff to the organization & 0.72 \\
To meet future skill requirements & 0.75 \\
To redeploy staff to other roles & 0.69 \\
$* p<0.001$ &
\end{tabular}
$* p<0.001$ 
Table 5. CFA of TM practices

\begin{tabular}{lc}
\hline Factors & Standardized regression weight* \\
\hline Work-based systems (TMP1) & 0.59 \\
Networking & 0.77 \\
Internal project teams & 0.79 \\
Special tasks to stimulate learning & 0.77 \\
In-house development programs & 0.84 \\
Cross disciplinary project working & 0.67 \\
Instructor-led off the job training & 0.76 \\
Formal career plans & \\
\hline HRM-led systems (TMP2) & 0.63 \\
Coaching & 0.73 \\
Mentoring & 0.80 \\
Assessment centres & 0.68 \\
Graduate development programs & 0.76 \\
Succession plans & 0.79 \\
High flier schemes & 0.66 \\
University courses & \\
\hline International systems (TMP3) & 0.95 \\
Training in international operations & 0.87 \\
Short term international systems (<12 months) & 0.91 \\
International project teams & \\
\hline Career portfolio building (TMP4) & 0.64 \\
Internal secondment & 0.76 \\
Job rotation & 0.76 \\
External secondments & \\
* $<0.001$ & \\
\hline
\end{tabular}

$* p<0.001$

Table 6. Goodness of fit statistics

\begin{tabular}{|l|c|c|c|c|c|c|}
\hline Model/Construct & $\boldsymbol{\chi} \mathbf{2}$ & $\boldsymbol{\chi 2} / \mathbf{d f}$ & $\mathbf{R M R}$ & GFI & AGFI & CFI \\
\hline TM motives & 127.81 & 3.87 & 0.04 & 0.89 & 0.82 & 0.91 \\
\hline TM practices & 369.58 & 2.42 & 0.08 & 0.85 & 0.80 & 0.93 \\
\hline
\end{tabular}


Table 7. Correlation matrix

\begin{tabular}{|c|c|c|c|c|c|c|c|c|c|c|}
\hline Variable name & Definition & 1 & 2 & 3 & 4 & 5 & 6 & 7 & 8 & 9 \\
\hline 1. TMM1 & Strategically orientated & 1.00 & & & & & & & & \\
\hline 2. TMM2 & Tactically orientated & 0.00 & 1.00 & & & & & & & \\
\hline 3. TMP1 & Work-based systems & $0.33 * *$ & $0.29 * *$ & 1.00 & & & & & & \\
\hline 4. TMP2 & HRM-led systems & 0.10 & $0.17 *$ & 0.00 & 1.00 & & & & & \\
\hline 5. TMP3 & International systems & 0.13 & 0.11 & 0.00 & 0.00 & 1.00 & & & & \\
\hline 6. TMP4 & Career portfolio building & $0.15^{*}$ & -0.06 & 0.00 & 0.00 & 0.00 & 1.00 & & & \\
\hline 7. SIZE & Subsidiary size & -0.03 & 0.09 & 0.01 & $0.22 * *$ & 0.08 & -0.03 & 1.00 & & \\
\hline 8. AGE (Ln) & Subsidiary age (Ln) & 0.02 & 0.03 & 0.01 & -0.01 & 0.07 & -0.03 & $0.22 * *$ & 1.00 & \\
\hline 9. INDUSTRY & Manufacturing vs. services & 0.11 & -0.06 & 0.09 & $-0.16^{*}$ & 0.09 & -0.01 & -0.11 & 0.13 & 1.00 \\
\hline
\end{tabular}

$N=201$ 
Table 8. Logistic regression results

\begin{tabular}{|c|c|c|c|c|c|c|c|c|c|c|c|c|c|c|c|c|c|}
\hline \multirow[b]{2}{*}{ Variables } & \multirow[b]{2}{*}{ Definition } & \multicolumn{2}{|c|}{ Model 1} & \multicolumn{2}{|c|}{ Model 2} & \multicolumn{2}{|c|}{ Model 3} & \multicolumn{2}{|c|}{ Model 4} & \multicolumn{2}{|c|}{ Model 5} & \multicolumn{2}{|c|}{ Model 6} & \multicolumn{2}{|c|}{ Model 7} & \multicolumn{2}{|c|}{ Model 8} \\
\hline & & Coefficient $\dagger$ & Nald-stat. & Coefficient & Wald-stat. & Coefficient & Wald-stat. & Coefficient & Wald-stat. & Coefficient & Wald-stat. & Coefficient & Wald-stat. & Coefficient & Wald-stat. & Coefficient & Wald-stat. \\
\hline \multicolumn{18}{|c|}{ Independent variables } \\
\hline TMM1 & Strategically orientated & & & 0.03 & 0.03 & & & & & & & & & & & -0.15 & 0.58 \\
\hline TMM2 & Tactically orientated & & & & & $0.84 * * *$ & 15.13 & & & & & & & & & $0.69^{* * * *}$ & 9.31 \\
\hline TMP1 & Work-based systems & & & & & & & $0.32 * *$ & 3.66 & & & & & & & $0.25 *$ & 2.09 \\
\hline TMP2 & HRM-led systems & & & & & & & & & $0.31 * *$ & 3.14 & & & & & $0.29 * *$ & 2.69 \\
\hline TMP3 & International systems & & & & & & & & & & & $0.52 * * *$ & 9.43 & & & $0.53^{* * *}$ & 8.53 \\
\hline TMP4 & Career portfolio building & & & & & & & & & & & & & -0.06 & 0.14 & -0.08 & 0.18 \\
\hline \multicolumn{18}{|l|}{ Control variables } \\
\hline SIZE & Subsidiary size & $0.56^{* * *}$ & 21.52 & $0.57^{* * * *}$ & 21.50 & $0.59^{* * * *}$ & 19.76 & $0.58 * * *$ & 21.60 & $0.53^{* * *}$ & 17.85 & $0.57 * * *$ & 20.59 & $0.56^{* * *}$ & 21.43 & $0.56^{* * * *}$ & 16.30 \\
\hline AGE (Ln) & Subsidiary age (Ln) & 0.08 & 0.19 & 0.08 & 0.19 & 0.04 & 0.05 & 0.08 & 0.17 & 0.09 & 0.24 & 0.06 & 0.11 & 0.08 & 0.19 & 0.02 & 0.01 \\
\hline INDUSTRY & Manufacturing vs. services & -0.37 & 1.36 & -0.38 & 1.39 & -0.37 & 1.19 & -0.43 & 1.74 & -0.31 & 0.88 & -0.49 & 1.77 & -0.37 & 1.37 & -0.45 & 1.47 \\
\hline Intercept & & $-1.99 * * *$ & 10.99 & $-1.99 * * *$ & 10.93 & $-2.01 * * *$ & 10.25 & $-1.99 * * *$ & 10.85 & $-1.97 * * *$ & 10.58 & $-1.92 * * *$ & 9.65 & $-1.98 * * *$ & 10.89 & $-1.89 * * *$ & 8.63 \\
\hline \multicolumn{18}{|l|}{ Reliability } \\
\hline Model $\chi^{2}$ & & \multicolumn{2}{|c|}{$21.47 * * *$} & \multicolumn{2}{|c|}{$29.51 * * *$} & \multicolumn{2}{|c|}{$48.79 * * *$} & \multicolumn{2}{|c|}{$33.30 * * *$} & \multicolumn{2}{|c|}{$32.72 * * *$} & \multicolumn{2}{|c|}{$39.44 * * *$} & \multicolumn{2}{|c|}{$29.62 * * *$} & \multicolumn{2}{|c|}{$59.93 * * *$} \\
\hline$R^{2}($ Cox \& Snell $)$ & & \multicolumn{2}{|c|}{0.08} & \multicolumn{2}{|c|}{0.14} & \multicolumn{2}{|c|}{0.21} & \multicolumn{2}{|c|}{0.15} & \multicolumn{2}{|c|}{0.15} & \multicolumn{2}{|c|}{0.18} & \multicolumn{2}{|c|}{0.14} & \multicolumn{2}{|c|}{0.26} \\
\hline$R^{2}$ (Nagelkerke) & & \multicolumn{2}{|c|}{0.12} & 0.1 & 19 & 0.2 & 29 & 0.2 & 21 & 0.2 & & 0.2 & & 0.1 & & 0.3 & \\
\hline Sensitivity & & 0.5 & & 0.5 & 52 & 0.5 & 54 & 0.4 & 48 & 0.4 & & 0.5 & & 0.5 & & 0.6 & \\
\hline Specificity & & 0.8 & & 0.8 & 34 & 0. & 90 & 0.8 & 83 & 0.8 & & 0.8 & & 0.8 & & 0.8 & \\
\hline Correct ratio & & 0.7 & & 0.7 & 22 & 0.7 & 77 & 0.7 & 71 & 0.7 & & 0.7 & & 0.7 & & 0.7 & \\
\hline
\end{tabular}

Notes:
$\uparrow$ Positive signs indicate a higher likelihood of MNE subsidiaries in Turkey, while negative signs indicate a higher likelihood of domestic Turkish firms.

$* p<0.1 ; * * p<0.05 ; * * * p<0.01$

$N=201$. 
Figure 1. Research framework

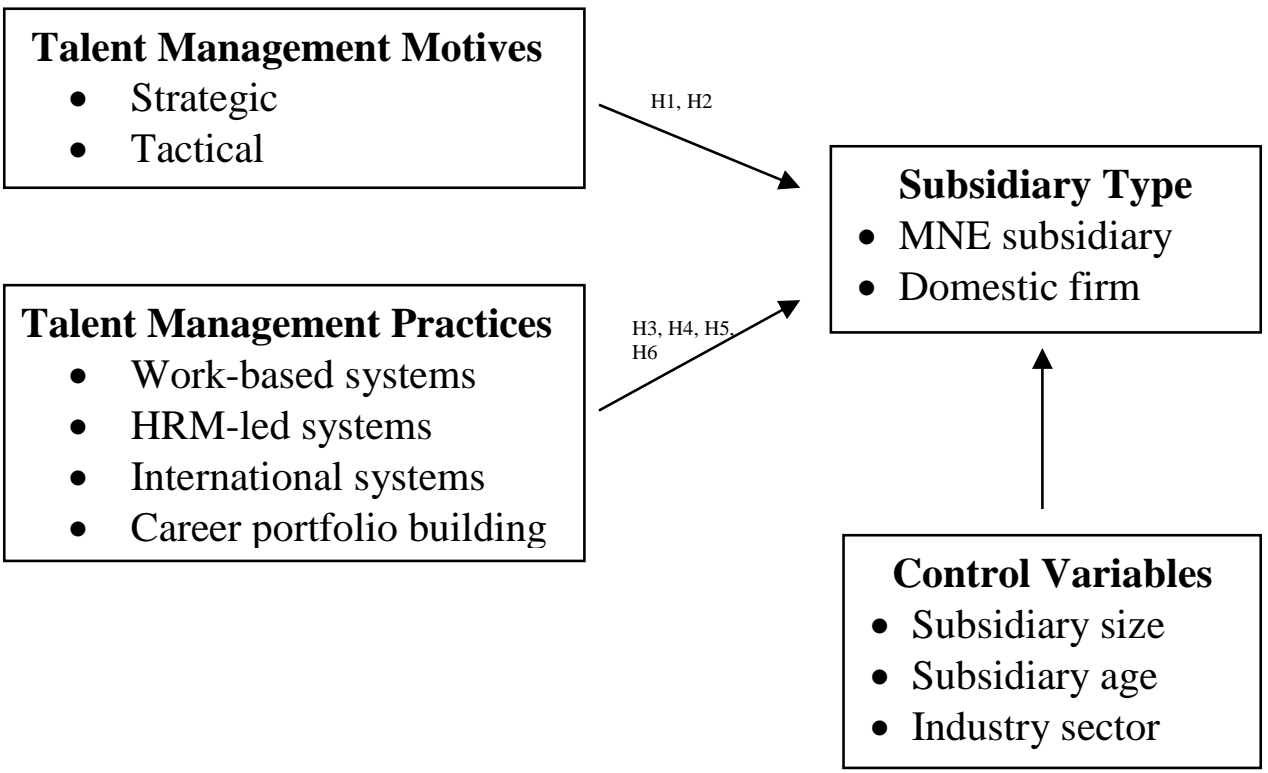

